\title{
The General Portrayed: Sir Arthur Currie and his Painters
}

\section{by Robert H. Michel}

Artists played an important part in propagandizing, documenting, and memorializing the battles and leaders of the First World War. Numerous artists portrayed General Sir Arthur Currie, Commander of the Canadian forces in the First World War and later Principal of McGill University. The portraits, together with related correspondence offer new glimpses of Currie and his wide variety of painters. This study rounds out Currie's visual portraits with a few verbal ones, and touches on the entrepreneurial side of portraiture, the neglect of Canadian war art, the famous, maligned military groups by John Singer Sargent and Emily Warren, the prestige of painting over photography, and Currie's own views on art.

Les artistes ont joué un rôle non négligeable dans la propagande, l'illustration et la commémoration des batailles et héros de la Première Guerre mondiale. De nombreux artistes ont peint le portrait du général Arthur Currie, commandant des Forces canadiennes pendant la Première Guerre mondiale puis principal de l'Université McGill. Les portraits, ainsi que la correspondance qui s'y rapporte, offrent de nouvelles perspectives sur Currie et ses multiples peintres. Cet article complète les portraits visuels de Currie par quelques portraits verbaux puis examine le côté entrepreneur de l'art du portrait, l'état d'abandon de l'art guerrier canadien, les célèbres et pernicieuses peintures militaires de John Singer Sargent et d'Emily Warren, la supériorité de la peinture sur la photographie et les opinions que Currie avait sur l'art.

$\mathrm{T}$ he military portraits of General Sir Arthur Currie (1875-1933) offer an unusual way to explore Currie's image and character, his relations with his portrait painters and his views on art. The stories of the portraits throw light on the painters' personalities and methods and, generally, on war memorial art. Portraits of Currie in uniform were commissioned during and after the First World War to honour the Canadian Commander and memorialize Canadian war achievements. This article concentrates on documented military portraits by eight painters: Richard Jack, Sir William Orpen, Eric Kennington, Joseph DeCamp, John Singer Sargent, E. Hodgson Smart, Robin Watt, and Emily Warren. Other portraits will be mentioned. In addition, there ure doubtless more paintings or sketches in military headquarters, legion halls, and other collections. Currie's correspondence with his portraitists comes from his records as Principal of McGill University in the University Archives, proving that institutional reconds may illuminate unsuspected topics. Currie's papers at the National Archives of Canada and the records of the National Gallery of Canada also document the portraits and artists. ${ }^{\prime}$
Born in 1875 in Ontario, Currie taught school, sold real estate, and served in the militia. When the First World War broke out eighty years ago, Currie soon rose to command the First Canadian Division. The war helped forge the Canadian identity; the Canadian forces pressed the Germans at the Second Battle of Ypres, at Vimy Ridge, and during the last Hundred Days leading to victory. In June 1917 General Currie became the first Canadian to command the Canadian Corps. A loyal imperialist, Currie fought as a Canadian, and proudly noted in his diary that the Canadian generals "have seen more war in the last three years than the British Army did in its previous 100 years. "2 His biographers, Urquhart, Dancocks, and Hyatt, argue convincingly that Currie brilliantly mastered the complexities of modern war and, contrary to allegations, fiercely conserved his mens' lives. ${ }^{3}$ After the war, Currie lobbied for veterans' benefits and helped many returned soldiers find jobs. He spoke at hundreds of war remembrances and dedications; he memorialized the war for Canadians. Advanced by war, he tirelessly advocated world disarmament. He declared in 1924: "War is not a means to establish peace. It is a delusion and a lie.... we must take up the challenge to contend and sacrifice for the upbuilding of humanity. " 
In 1920 while Currie served as Inspector-General of the Canadian forces, McGill University sought a Principal. The outgoing Principal Auckland Geddes and the Master of Balliol both recommended Currie to McGill Governor William Birks. According to General F. Loomis, Lord Shaughnessy also may have influenced Currie's appointment; he was indebted to Currie for assigning his son to his staff during the war. ${ }^{5}$ Long before Eisenhower led Columbia, Currie proved that generals could direct universities. From 1920 until his death in November 1933, he managed McGill with vision in spite of tight finances, winning over both students and staff; Stephen Leacock became a great admirer. Currie had long pushed for a gymnasium. After his death, McGill graduates funded the Currie Memorial Gymnasium-Armoury. It opened in time to drill men for the Second World War - the war Currie had foreseen and dreaded.

\section{CANADIAN WAR MEMORIAL ART}

During the First World War, art played a new role as propaganda and documentation - and even as a weapon, through the invention of dazzle painting on ships to confuse enemy gunners. War art has at least three functions: during the war it shows achievements; next it serves as a war memorial and finally as a historical record. ${ }^{6}$ Sir Max Aitken (later Lord Beaverbrook) handled Canadian interests at the front. $\mathrm{He}$ admired the propaganda value of photograpbs and film but he believed that only painting could offer a permanent, prestigious record of Canadian valour. In November 1916 Aitken and Lord Rothermere set up the Canadian War Memorials Fund to produce "suitable Memorials in the form of Tablets, Oil-Paintings etc., to the Canadian Heroes and Heroines in the war." Artists would be given army commissions and paid by the Canadian government. At the war's end the pictures would go to Canada and be housed with war trophies in a memorial hall. ${ }^{7}$ Paul G. Konody (1872-1933), Art Advisor to the Canadian War Memorials Fund, proclaimed that war's purpose was to kill, art's to explain; that war was a boon to artists, and that the War Memorials provided an ideal system of patronizing art. ${ }^{8}$ The Canadian war artists would include $M$. Cullen, F.H. Varley, J.W. Maurice, and A.Y. Jackson. The war artists painted portraits as well as battle scenes. As will be seen, Currie sat to Sir Willian Orpen.

In January 1919 the Royal Academy exhibited ove 350 Canadian War Memorial works; a gallery of Canadian photographs was shown at the same time. Currie and Prime Minister Borden spoke at the openings. Art critics noticed that the new styles such as cubism and vorticism suited scenes of battle; modem art and modern war both destroyed tradition. The pictures toured Canada but war patriotism faded; the planned hall never materialized. As early as 1922, Hector Charlesworth in Saturday Night fumed about the pictures' banishment to the National Gallery of Canada's basement. ${ }^{10}$ Half a century later, the National Gallery transferred most of the works to the Canadian War Museum, which lacks the facilities to display what are perbaps the finest holdings of war art on earth - a sad fate for a collection that, in Heather Robertson's words, "perfectly expresses the eternal tragedy of war. ${ }^{n 11}$

\section{RICHARD JACK, CA. 1917 AND THE MIND/ BODY DICHOTOMY}

Major Richard Jack (1866-1952), an Englishman and Canada's first official war artist, painted Currie's first large military portrait (Figure 1). Although the portrait had been privately arranged, its exhibition at the Royal Academy in 1917 encouraged official support for Canadian war art. ${ }^{12}$ During the Royal Academy show, the London magazine Sphere reproduced the Jack portrait on its cover of 18 January 1919. Currie had become friends with Major Jack; in his diary he mentioned visiting Jack's studio and a dinner party after which Jack sang. ${ }^{13}$ In April 1919, General Loomis and others presented the portrait to Lady Currie who with the children Garner and Marjorie had spent much of the war in England. ${ }^{14}$ By 1948 Lady Currie had lent the portrait to McGill. In 1957 she sold it to the University for its insured value of $\$ 6000$., assuring Chancellor Gardner that she was glad the portrait would remain at McGill. ${ }^{15}$ It hangs in the finely crafted War Memorial Hall of the Currie Gymnasium.

Jack's three-quarter-length portrait shows Currie (in his early forties) as he looked during the war; six feet 
The General Portrayed

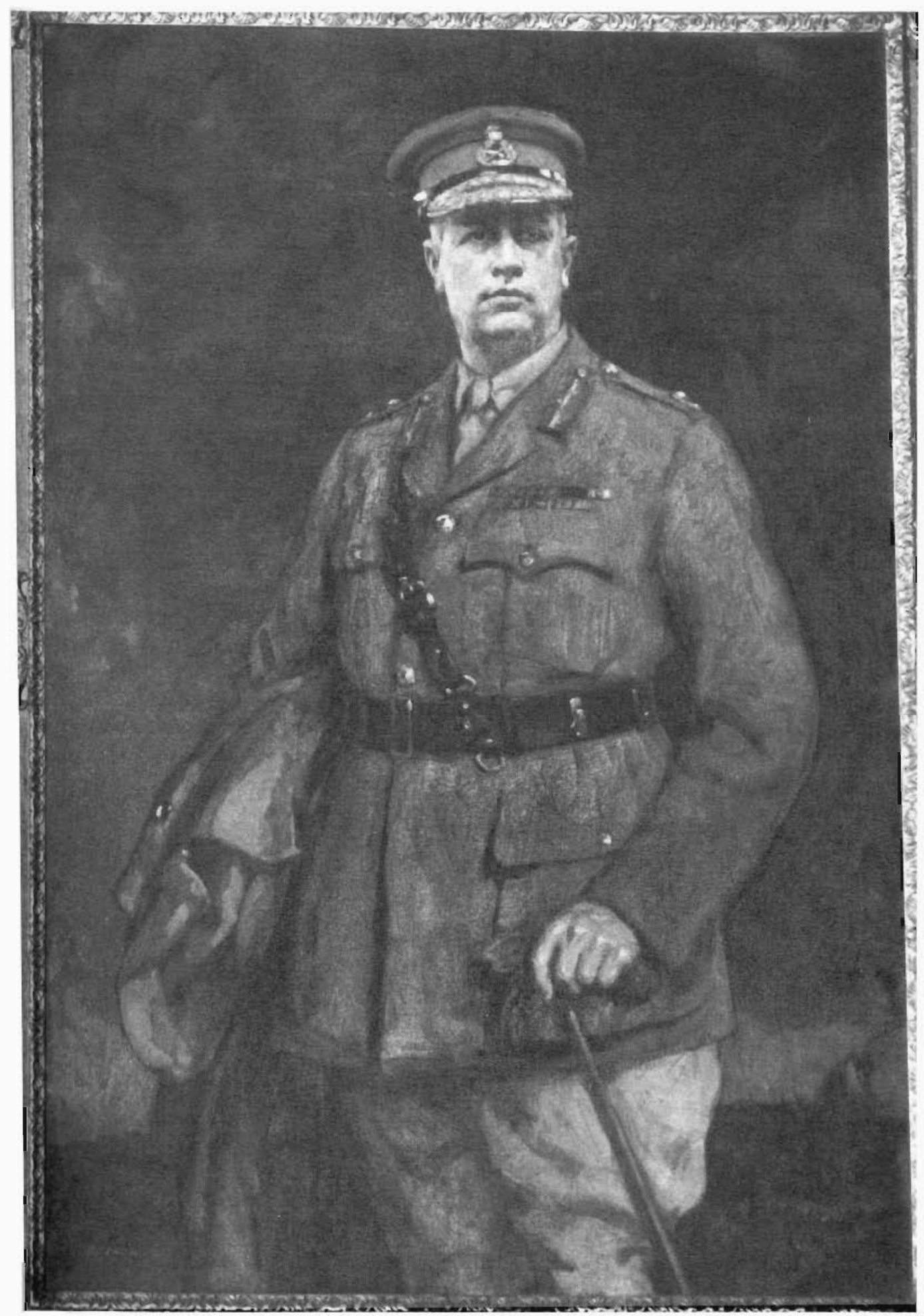

Figure 1. By Richard Jack. Oil on canvas, 170 x $126 \mathrm{~cm}$., 1917. Sir Arthur Currie Memorial Gymnasium Armoury, McGill University. 
The General Portrayed

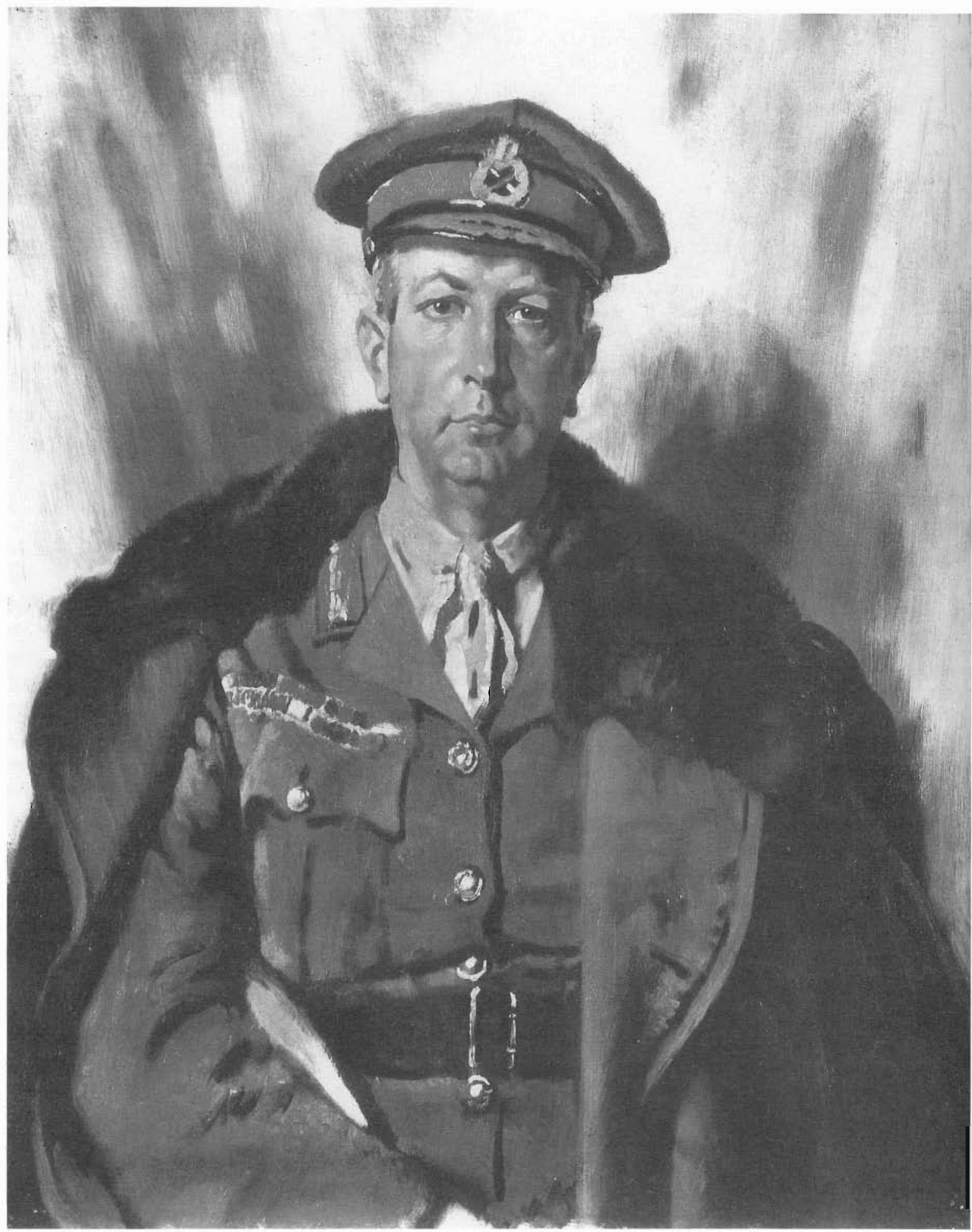

Figure 2. By Sir William Orpen. Oil on canvas, $91 \times 76 \mathrm{~cm}$., 1919. Canadian War Museum, Ottawa (CN\#8673, $\left.{ }^{\circ} \mathrm{CWM} 1994\right)$ 


\section{The General Portrayed}

three inches tall, stout, weighing well over 200 pounds; his face young, rounded and unclouded. ${ }^{16}$ Painter and sitter shared impressive size: Jack stood six feet seven inches and weighed nearly 300 pounds. ${ }^{17}$ Fellow officers often pointed out the contradiction they found between Currie's big, soft, cherubic appearance and his tough intellectual power and courage. They had to overcome their stereotyped view that weight meant sluggishness. In the 1930 s a few officers sent verbal portraits to Currie's biographer Urquhart, which add perspective to those in oil. General E.S. Hoare-Nairne remembered that at first glance Currie looked childlike:

The next impression was of a man, rather reticent in speech, of great physical strength; physically a "strong man" rather than an athlete, with massive sloping shoulders and rather awkward legs, slow in movement. His smooth, almost babyish face, was a puzzle, for one knew, by reputation, that he had proved himself a man of great courage and decision in situations of stress and anxiety and danger, which left their mark on other men's features. Later still, the explanation seemed to me to be that Currie's spirit was of such finely tempered quality that it could not be scarred by the stress of events which left their mark on us lesser men. By the end of the war he did bear some of its strain in his face, but he had in him, I imagine, a faith or quality of spirit which allowed him to be serene when many others were worried, confident when others were doubting. I believe that this intangible spiritual quality was the main basis of Currie's tremendous prestige. ${ }^{18}$

Colonel Harry Crerar observed that Currie had a corpulent "unsoldierlike" figure:

He looked the reverse of a great soldier, and a leader, to the superficial glance. His eyes, and the steadiness of them, his observations (not his speeches - which to my mind were generally too studied and flowery) and the directness and sincerity of them, provided the first evidence of his character and ability.

Crerar admired Currie's colossal memory and concern for lives of his men. ${ }^{19}$ General Gilbert Frith used Currie's largeness as a metaphor for the kind of biography Urquhart should write:
Currie was a big man in every way and his portrait should be boldly drawn with little detail. The moment one begins to fill in detail the faults, and there were many, begin to appear and it is these the little men will seize on to try and destroy his reputation. A big bold picture gives no grip for their petty minds.

Though Currie lacked the lean craggy features and carriage of officers like Sir Douglas Haig ${ }^{21}$, he had an engaging, quizzical, businesslike mien that hinted at his ability to size up situations and work well with other generals. Once officers and artists knew Currie, they used his awkward size or immature face as a springboard to discover his inner character and charm. Furthermore, Currie's portraitists after Jack caught a leaner, tougher look; that of the commander who worked seventeen hours a day and won all his objectives. As Currie aged, he grew more distinguished. The man in the retrospective military portraits of the $1920 \mathrm{~s}$ ran a University, went on speaking tours, advocated veterans' rights, and worked to exhaustion; his face in his later photographs gained a Roman nobility.

\section{WILLIAM ORPEN, 1919 - AN UNSATISFACTORY PORTRAIT}

Beaverbrook arranged for the fashionable portraitist, Sir William Orpen (1878-1931), to paint several Canadian generals, in Paris in early 1918. These portraits were to be the basis for a group of the four Canadian Divisional Commanders with Currie. ${ }^{22}$ Orpen may have dragged his feet; he complained that Beaverbrook's demand for Canadian portraits prevented him from doing battlefield subjects. Strongly supporting war memorial art, Currie wrote to Beaverbrook in January 1918, suggesting that Orpen's group would have more historical value if five more officers of his Headquarters Staff could be added to it. Beaverbrook replied that if Orpen had not yet started he would be told to add the extra five; otherwise he would do a second group of Currie with the five officers. ${ }^{23}$ So much for artistic autonomy!

Though Orpen may have already sketched Currie in early 1918, Currie recorded sittings for his full-fledged portrait for the War Memorials in his rooms at the Ritz 


\section{The General Portrayed}

Hotel in Paris during the opening of the Peace Conference in late February and early March 1919. ${ }^{24}$ Currie grew to hate the result (Figure 2). He felt it did not look like him; he may also have found the style flashy. Something had spoiled the artistic brew. Lady Currie had been very ill during the sittings. Currie looked glum; perhaps he worried about her as he sat or later disliked the anxieties the portrait rekindled. Or he may not have hit it off with the emotional Orpen, who had little respect for generals and statesmen and preferred to paint his pretty French mistress as a war refuge. ${ }^{25}$ After the war, the portrait toured Canada with the Canadian War Memorials and then went with the rest to the National Gallery of Canada.

When the Orpen portrait was displayed in a War Memorials exbibition in 1924, Currie requested Sir Edmund Walker, Chairman of the Board of Trustees of the National Gallery, to remove it:

There is in the Gallery a portrait of myself painted by Sir William Orpen. I know that Sir William was frankly dissatisfied with that portrait. In fact he said to me that some time he was coming to Canada to paint another portrait, as he would not care to see the present one remain the permanent record of his effort to paint me. I have never met anyone but who disliked the present portrait, except, of course, my enemies, who may regard it as satisfactory. I cannot imagine that at any time I looked as Orpen has portrayed me, and I think it unfair to future citizens of Canada, to Canada's war effort and to myself, to have that portrait handed down to posterity as a likeness of the Canadian Corps Commander.

I am very much in earnest about this, Sir Edmund, and I would like the Committee to give favourable consideration to my request to remove that portrait from the National Gallery.

Walker replied immediately that the portrait would be withdrawn from the exhibition. ${ }^{26}$

Irked that the Orpen remained his official portrait, Currie may have lobbied quietly for a replacement. Currie's old comrade, John Arthur Clark, was the Conservative M.P. for Vancouver-Burrard. Clark had commanded the 7 th Canadian Infantry Brigade which had made the controversial last hour capture of Mons on 11 November 1918. In 1928 Currie had won a libel suit in Cobourg, Ontario vindicating him against old rumours of throwing away lives at Mons. When in 1929 Parliament voted $\$ 85,000$ for new pictures for the National Gallery, Clark seized the chance to propose to the Gallery's director, that some of the funds go towards a new portrait of Currie:

I have seen the portrait by Orpen, and it does not do him justice. I am strongly of the opinion that a Canadian who has made history, as General Currie has done, should bave a place in the country's National Gallery. Such a portrait should be painted by the best artist available and, in my opinion, no time should be lost in securing it. $^{27}$

The Orpen portrait brought out Currie's concern with his public image. He must have been further frustrated by the fact that it had been copied by T. Loxton Rawbon (1855-1942) for the Sir Arthur Currie Hall at the Royal Military College in Kingston. On 17 May 1922 Currie watched the undraping of his portrait, which officially opened the Hall. Rawbon had copied Orpen's portraits of the other Canadian generals for the Hall so Currie could not really complain. Designed and decorated by Currie's McGill architecture professors, Percy Nobbs and Ramsay Traquair, the Hall is Currie's and the Canadian Corps' greatest war memorial. ${ }^{28}$

\section{ERIC KENNINGTON, 1919 - A CALM PRESENCE}

In January 1919 Eric H. Kennington (1888-1960) sketched Currie in Bonn. A founding member of the New English Art Club, he turned from illustration to portraits. He enlisted as a private in 1914, was invalided out, and returned as a war artist. Unlike A.Y. Jackson, Kennington tended to hero-worship the men and officers he drew. ${ }^{29}$ While Kennington served in the army occupying Germany, his department (Intelligence) ordered him to do the portrait. As Commander, Currie lived in great style in the Kaiser's suite at Schaumburg Palace; he found it: "the most comfortable place I have yet been in during the war." He noticed with surprise that many of the books were English, "all of our well-known authors being represented", while on the walls hung pictures of England and the British Royal Family. ${ }^{30}$ 


\section{The General Portrayed}

Kennington recalled the strong impression Currie made on him:

I was billeted near Cologne with the army of occupation, Jan 1919. My department (Intelligence) ordered me to obtain, at Bonn, a portrait of Currie. I think he was staying at the Kaiser's palace.

He sat as only a soldier can, \& I was at the same time dominated by his vast, Buddistic [sic], calm presence, \& charmed by his deference, \& shrewd interest in all my world. He had immense dignity. "131

Rennington's sketch (Figure 3) wonderfully exaggerates Currie's physiognomy yet conveys the sober dignity and directness which characterized Currie as General and MeGill Principal.

\section{JOSEPH DECAMP, 1920-1921 — THE AMERICAN PORTRAIT}

For the portraits after 1919, Currie put on his old uniform to become Commander once more. None of the portraits betray that they are reenactments. Joseph R. DeCamp (1858-1923) painted Currie in 1921. Trained in the Royal Academy in Munich, DeCamp settled in Boston in 1884. A member of the Ten American Painters group, he won many medals. He taught at the Massachusetts Normal Art School (19031923), stressing drawing, composition and academic training. He married a pupil and had four children. When his studio burned in 1904 , he raised money to feed bis brood by painting portraits at a discount; he soon excelled at sober portraits of men and lighter, freer portraits of women. ${ }^{32}$

In cooperation with the Smithsonian Institution's National Gallery of Art (now the National Museum of American Art), a National Art Committee was formed in 1919 to commission prominent artists to paint the Allied leaders. The Committee hoped sponsors in various American cities would pay for the portraits, estimated to cost about $\$ 8,000$ each, including travel expenses. The sponsors would then present them to the Smithsonian's National Gallery of Art in the name of their cities. ${ }^{33}$
In September 1919 the Committee asked Currie to sit for Irving Wiles. Currie accepted, congratulating the National Art Committee "on their esprit-de-corps". In May 1920 Currie corresponded with Wiles but illness forced Wiles to withdraw from the project. Currie was informed that he and Robert Borden would be painted instead by DeCamp, "whom no less authority than John Sargent considers the best portrait painter in the United States." Currie, still Inspector-General, arranged for DeCamp to visit his headquarters in Ottawa in mid-June $1920 . .^{34}$

After the sitting, DeCamp wrote three appeals for Currie to send the military ribbons he needed to finish the portrait. Obviously, he was on informal terms with Currie; he chided the General as few others dared. By December 1920 , he was desperate. The portrait had to be exhibited in a month.

The ribbons you promised bave not yet appeared. I have dictated you several tender epistles upon this subject.... Your portrait is almost finished and I am extremely anxious to get it away. If something doesn't happen about it pretty soon I may be obliged to tell your good wife.

Currie finally replied on 13 December 1920 that he was sending the ribbons: "I am glad to know that the portrait is nearly finished and I hope you are satisfied with it. "135

The ribbons came in the nick of time for the opening show of the war portraits at the Metropolitan Museum of Art in New York in January 1921; the catalogue pointed out that some of the portraits, Currie's and Borden's among them, were still available for American cities to present to the National Gallery. The portraits visited twenty-six cities before closing in June 1923. Though not sponsored, Currie's portrait went to the Smithsonian's Gallery with the others. As time passed, interest died and the portrait series descended from their own "Peace Room" in the National Gallery of Art to the vaults, a fate similar to that of the Canadian war pictures in Ottawa. Currie seems to have liked the portrait (Figure 4). DeCamp caught the steady gaze noted by Colonel Crerar. Frederick Platt described how Currie appeared: "Against sand and sea and stormy sky, he is erect and alert in this portrait. ${ }^{n 6}$ 
The General Portrayed

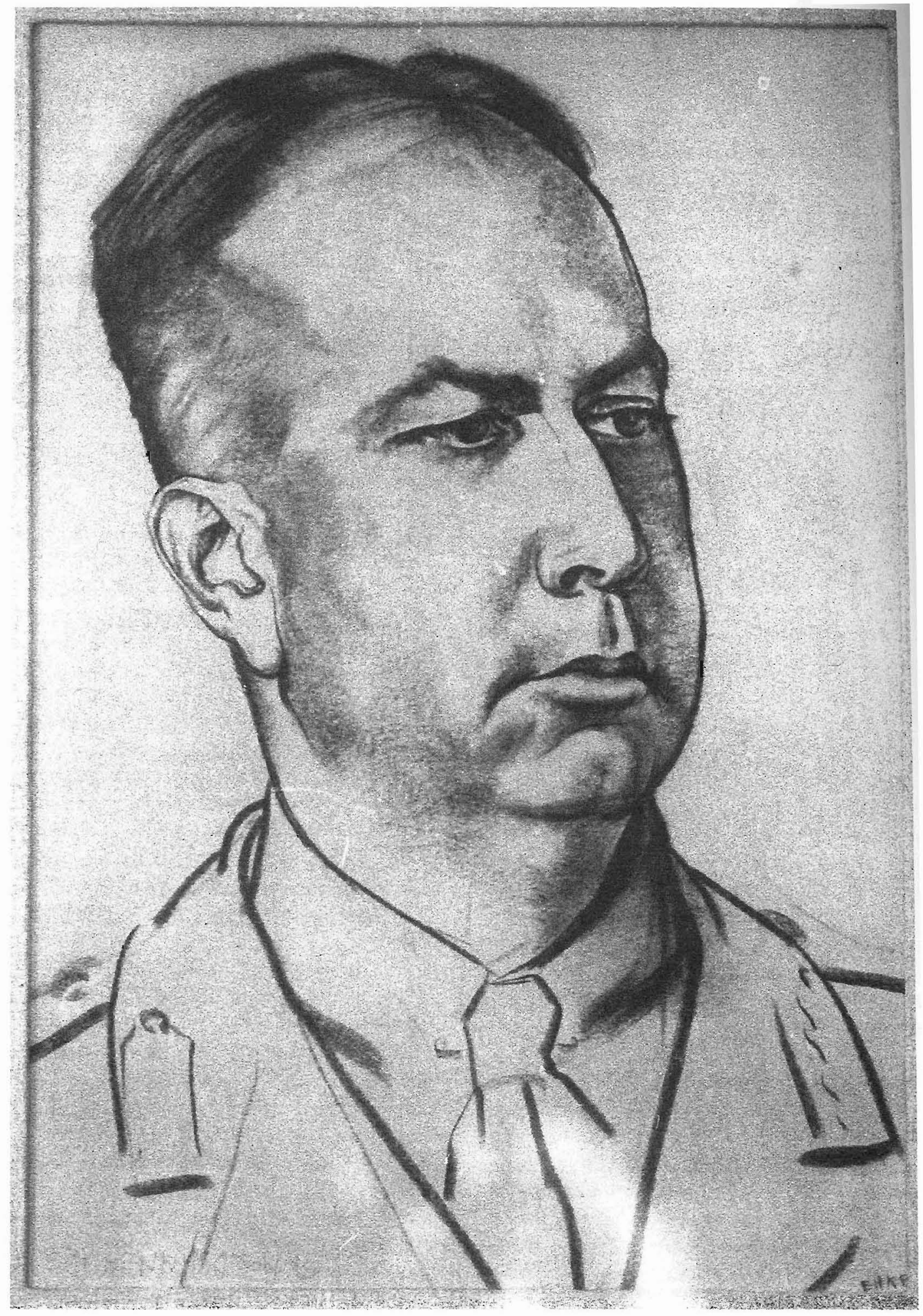

Figure 3. By Eric Kennington. Charcoal on paper, 50 x $35 \mathrm{~cm}$., 1919. Faculty Club, McGill University. 


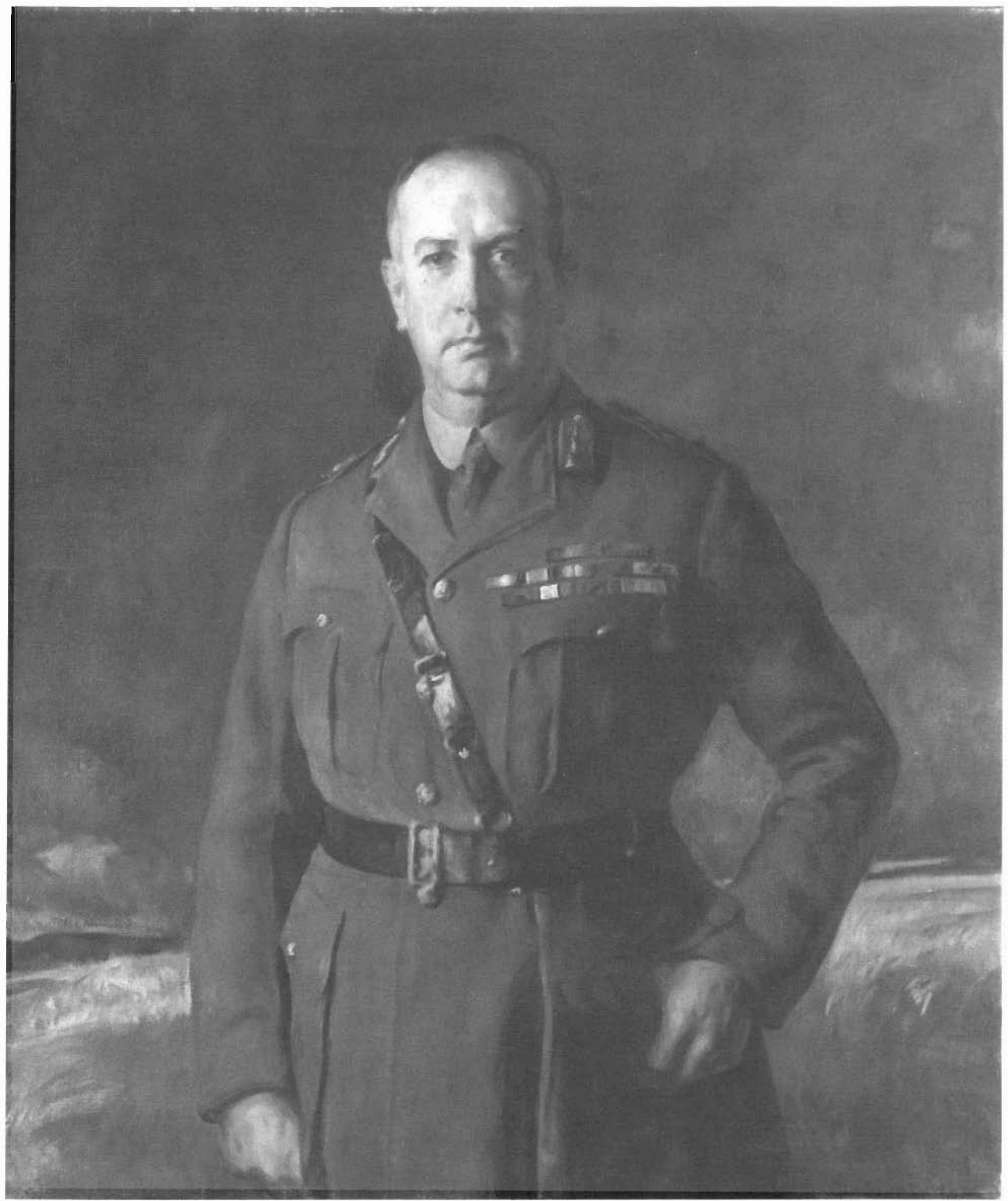

Figure 4. By Joseph DeCamp. Oil on canvas, $112 \times 97 \mathrm{~cm}$., 1920. National Museum of American Art, Smithsonian Institution, Washington, D.C. 


\section{The General Portrayed}

\section{JOHN SINGER SARGENT, 1921 - "IF YOU HAVE YOUR KHAKI UNIFORM"}

Currie appears in the monumental group portrait by John Singer Sargent (1856-1925): "Some General Officers of the Great War". Sir Abe Bailey (18641940), a South African financier and politician, cotmomissioned three pictures, to consist of the most important political, army, and naval figures of the War, for the National Portrait Gallery in London. Each painter would receive $£ 5000$. In January 1919 Sargent reluctantly agreed to do the army group out of duty, to help memorialize the British war effort. He recommended that Sir Arthur Cope and Sir James Guthrie be invited to do the other groups. At this point in his career, Sargent had tired of portraits; he wanted to concentrate on his allegorical mural projects in Boston, on which be pinned his hopes of immortality. ${ }^{37}$

Sargent hated the project and foresaw failure. $\mathrm{He}$ had to track down each general and paint his portrait. Then he had to copy the portraits on to the previously painted bodies - rather like gluing on heads for composite photographs. By September 1920 he had done some of the portrait studies. Pessimistically, he wrote to Sir James Guthrie (who had been assigned the politicians):

I find each of them individually very interesting to do and the tremendous variety of types seems to give a promise of some sort of interest. But I am still merely collecting material and have not yet evolved any scheme of the picture as a whole. ${ }^{38}$

While he liked his individual sketches, he predicted "united we will fall." He frequently lamented: "How am I going to paint twenty-two pairs of boots?" In worse moods, they became "bloody boots". Orpen too had found military groups boring. Commissioned to paint them at the Peace Conference in 1919, he declared: "a mass of Khaki is a dreadful thing to manage. ${ }^{.39}$

Sargent worked in London and Boston, sailing back and forth once or twice a year. Currie's correspondence with Sargent shows how the painter tracked down one of his dreaded generals. In August 1920 the Director of the National Portrait Gallery,
London, requested Currie to give sittings to Sargent. In September 1920 Currie wrote Sargent that he hoped to be in London in June 1921 and would write later. Sargent replied that he would be in Boston for much of 1921; did Currie plan any trips to Boston? Otherwise he would try to go to Montreal. In May 1921 Sargent decided he should get Currie out of the way:

I find that my work here in Boston [is] likely to detain me all summer... Would it be possible for you to give me an hour or two on two consecutive days? I should be grateful for any date you could appoint, giving me a few days notice....

Sargent was decorating the rotunda of the Boston Museum of Fine Arts. It is striking how little time be needed for Currie's sitting, given the resulting oil portrait and pencil sketches described later. Currie replied that he would be leaving for England by midJune but would be available most days until then: "Let me have a day's or so, notice of your coming."

On 19 May 1921 Sargent proposed the mornings of 6 and 7 June for the sittings:

If you have your khaki uniform so much the better, as that is what is required for the picture.

Another requirement is a top-light, rather than a usual window - and a room without sunlight. Perhaps you may know of some rooms in the University, or of some artist's studio, that would afford these conditions, and it would save time to have them discovered beforehand. If I knew anybody in Montreal I would not run the risk of imposing upon your good nature by mentioning these preliminaries."

For harmony and realism, the light source had to be consistent. Sargent needed to avoid dramatic or angular side lighting so that the individual heads would not be at odds when painted on to the prepared bodies. It was most efficient to do all the life sketches with the light coming from above. In the finished group, most of the lighting comes from above.

Currie replied on 20 May 1921: 


\section{The General Portrayed}

Regarding the 6th and 7 th of June, I am afraid the mornings of those days are taken up, but I shall be very glad to give you the time you require in the afternoon. On the morning of the 6th there is a meeting of the Board of Governors of the University, and on the morming of the 7 th there is a meeting of the Directors of the Bank of Montreal.

I shall make arrangements for the necessary room and let you know later. ${ }^{40}$

There is no further correspondence but the sittings took place as planned. Sargent died in 1925; the works in his studio, including oil sketches of many of the generals, were auctioned at Christie's. ${ }^{41}$ Currie's portrait was not among them.

Two surviving sketches of Currie, and reference to a third, show how Sargent painted Currie and put his group together. He painted a life-size head and shoulders in oils and drew a pencil portrait and a rendition of how Currie would stand in the group. In 1927 F.W. Cowie obtained two pencil sketches of Currie from Sargent's sisters. He presented them to Principal Currie, who passed the larger one on to the University Librarian, Gerhard Lomer, to be hung in the Library. ${ }^{42}$ This sketch bas not been found. The smaller sketch, which appears here is significant (Figure 5). ${ }^{43}$ Sargent had told Guthrie in September 1920 that as yet he had no scheme of the group as a whole. The sketch shows that by June 1921 Sargent had decided his overall design; it indicates exactly how Currie stands in the finished painting. It shows as well that Sargent decided to use Currie to break up the monotony by having him hold his coat - one of the few props in the painting. Finally, the sketch shows Sargent's concern that relative heights and body proportions be accurate; he noted on the sketch that Currie was six feet three inches tall and was seven and a half heads high. In a few deft strokes it catches Currie's stance and his features.

The oil sketch, the main basis for the group portrait, also survives (Figure 6). In this striking portrait, larger than the oil sketches of the other generals, Sargent caught his subject dramatically, in an effortless, painterly style. He has discovered a different man from Watt's intense planner or DeCamp's straight-forward officer; his Currie is relaxed, detached, mysterious.

Exhausted, Sargent finished the group portrait in Spring 1922. It forces fine individual portraits into a strange, disconcertingly static row. Currie appeared third from the right (Figure 7). ${ }^{44}$ Surprised critics regretfully panned the painting. Sir Claude Phillips wrote:

We stand before this immense canvas wholly disconcerted by its pale, anaemic aspect, by the absence of vigour and accent that it betrays. There is nothing here of a living rhythm, no serious attempt at a caesura of the almost unbroken line of great military personages who, impassive - we have almost said disdainful stand side by side yet isolated from one another, and from the spectator. ${ }^{45}$

Sargent's biographer Charteris declared that the picture had failed because Sargent had refused to take poetic licence:

These soldiers bad never been in one room together during the War, therefore it would be a falsification to group them as though they had. His adherence to fact stood between him and a work of art. The background, in his view, had to be neutral, carrying no import of time or place.... The Generals appear to be collected on a stage from which the curtain has just risen, and about to advance as a chorus to the footlights... ${ }^{46}$

Sargent had indeed refused the traditional duty of painters to invent and to improve on reality. $\mathrm{He}$ rebelled against 150 years of war art. Simon Schama demonstrated how Benjamin West's painting (1770) of the idealised death of General Wolfe bore no relation to fact but created a myth of heroism and patriotism. ${ }^{47}$ West painted what should have happened, not what had happened. His invention became the most famous scene in Canadian history; to this day it promotes Canadian nationalism and Quebec separatism. This kind of historical painting still dominated the genre in the 1920s and 1930s; painters tried to be novelists not historians. James Guthrie's "Some Statesmen of the Great War" presents a dramatic, active gathering broken up into discussions, with Winston Churchill seated at the centre gazing out at the viewer, dreaming, 


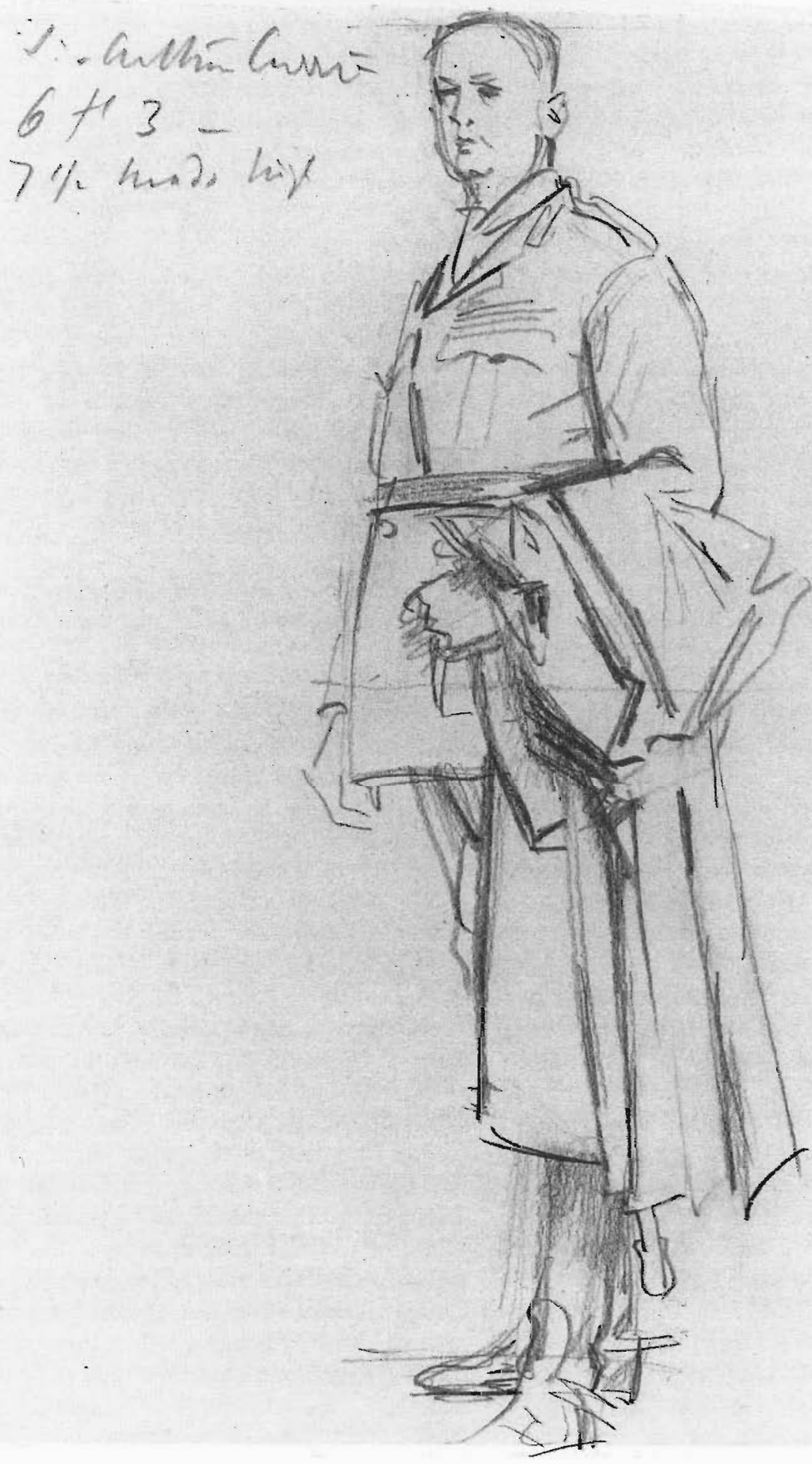

Figure 5. By John Singer Sargent. Pencil on paper, $26 \times 18 \mathrm{~cm}$, 1921. Department of Rare Books and Special Collections, McGill University Libraries. 
The General Portrayed

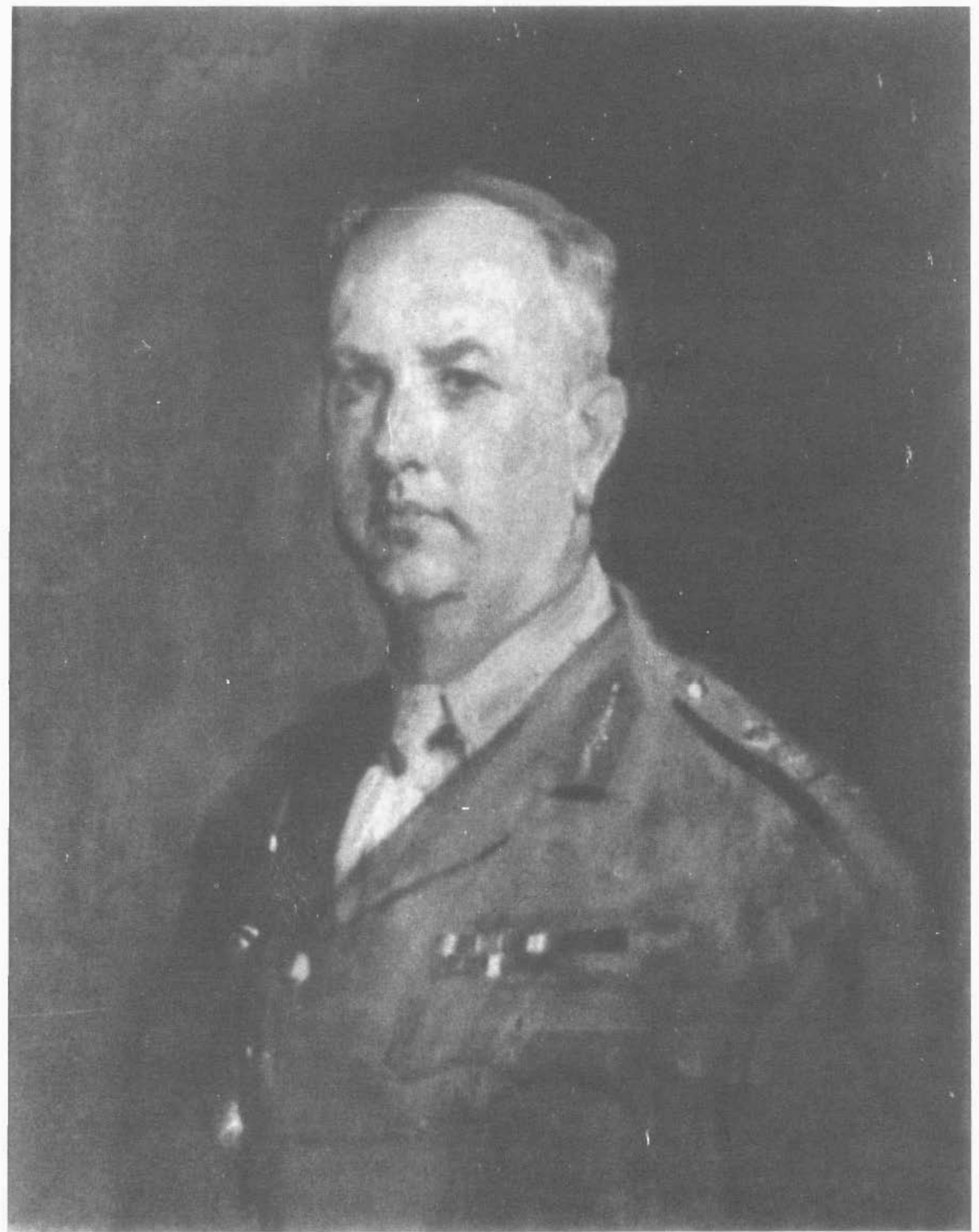

Figure 6. By John Singer Sargent. Oil on canvas, approximately $76 \times 61 \mathrm{~cm} ., 1921$. Private Collection. 


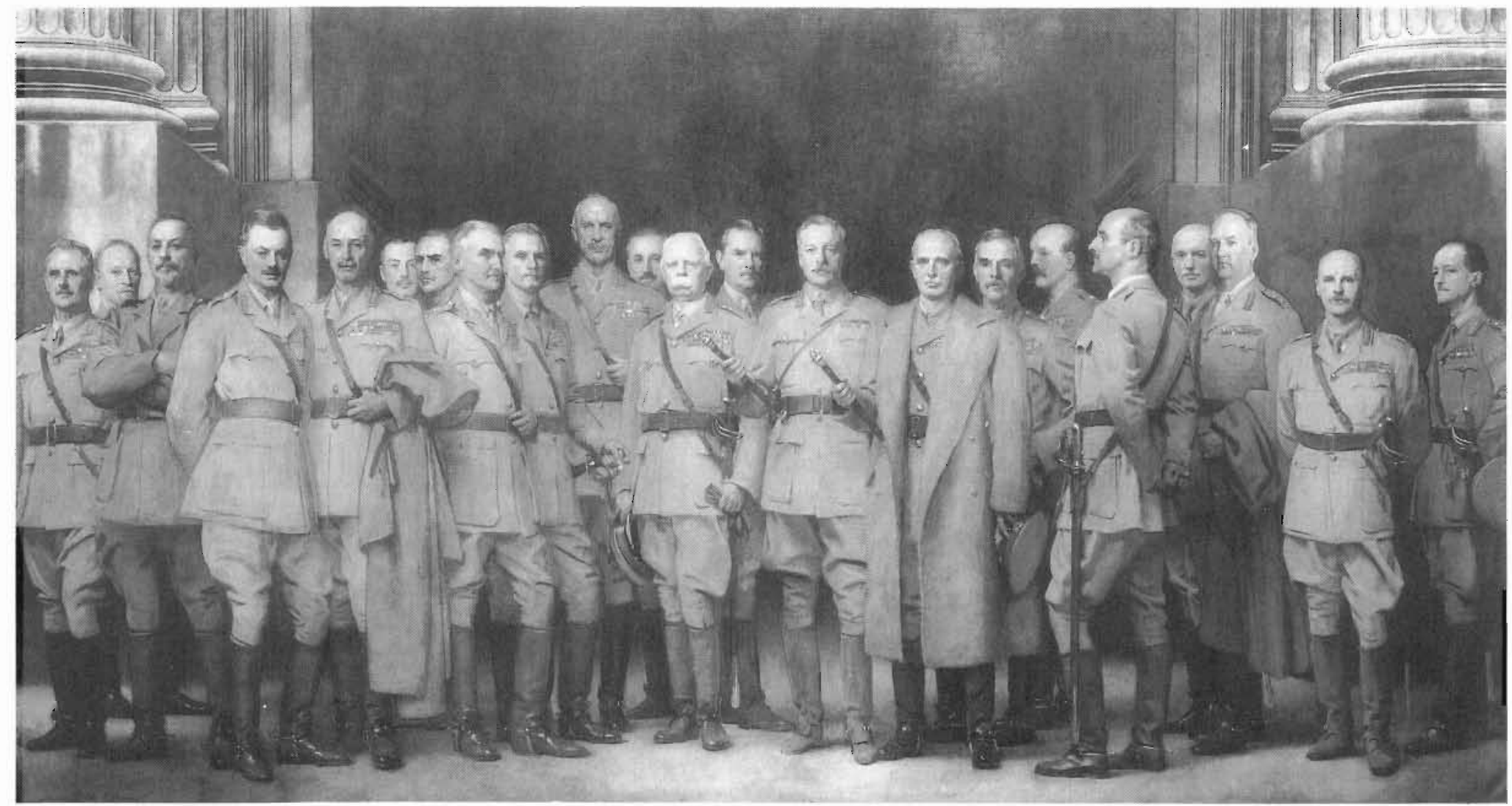

Figure 7. General Officers of World War I. By John Singer Sargent. Oil on canvas, 300 x $528 \mathrm{~cm}$., 1922. National Portrait Gallery, London. 


\section{The General Portrayed}

no doubt, of the war to come. ${ }^{48}$ Similarly, Arthur Cope broke his naval officers up into interactive groups in a realistic interior.

Contrarily, Sargent refused to animate his group; he had told Guthrie:

I am handicapped by the idea that they never could have been altogether in any particular place - so I feel debarred from any sort of interesting background and reduced to painting them all standing up in a vacuum. ${ }^{49}$

Sargent bad always captured spontaneity, light and abstract design interacting with recognizable forms. He had no trouble reconciling reality and exciting composition in his classical allegorical murals. But the recent war froze his imagination; he could not paint this group which never had gathered.

Against the art critics, it may be argued that the generals are far from being a failure but a triumph yet to be recognised. Sargent deserves credit for avoiding the histrionics of Guthrie and Cope - for his honesty in refusing to invent a dramatic, fictional scene to memorialize a war that had more than enough real scenes, many of them terrifying and ugly. His cold, elegant curtain call uncovered the impersonal, almost surreal face of modern war. As the best portraitist of his day, he refused to stage play a fake conference of the generals who had just won the greatest conflict of all time - a subject which Rembrandt or Van Dyke would have rolled up with glee. Perhaps it was the fault of the khaki uniforms or the loss of faith in war. The generals of 1918 looked worthy but banal; no charging horses or waving swords, no Caesars or Napoleons: only middle-aged spreads and balding heads. They had not led their men into battle; they were masterful planners but not heroic. Disappointed that few McGill boys turned out for a memorial service for Currie in 1937, Stephen Leacock observed that they remembered neither Currie nor the war: "and as modern military history does not run to spectacular victories, total defeats, and individual eminence, there is nothing for them to hear of General Currie that seems vivid to their minds. ${ }^{1150}$

If artists found generals uninspiring, they faced a harder problem; they could no longer portray battle scenes adequately. As A.Y. Jackson observed:
Knights in armour, bowmen and spearmen, the clash of arms, men and horses in a swirl of movement, this was the stuff battle paintings were made of in the early days, but with the introduction of gun powder and the increasing range of guns, the space between combatants grew wider in every war. In Napoleonic times a battle could still be visualized and the artist from an imaginary observation post could paint panoramas of moving masses of men in action.... The machine gun had destroyed the old death and glory picture which depended on a mass of cavalry or infantry hurtling forward with the shot riddled flag clutched in the stricken hero's hand.

In modern war, the battlefronts were too huge; the artist could only portray limited groups of soldiers and must "use the incidental to illustrate what is going on in endless repetition beyond his vision. "

\section{E. HODGSON SMART, 1924 - THE SCATTERED GALLERY}

At the end of February 1924, Currie received a request to paint him from Edmund Hodgson Smart (1873-1942), a British-born painter who worked in London and Cleveland. Smart had studied at Julian's in Paris under Bougereau. ${ }^{52}$ From Cleveland, Smart wrote mysteriously:

A Gallery of Oil Portraits of a selected number (not over 25) of celebrated men is being formed. It is of international importance \& as your portrait is desired I am writing to ask if you will give the necessary sittings. Directly I see you I will explain all the details, which are for the time being, kept entirely private, except to those whose portraits are for the Gallery. I should explain however that the financial end is already taken care of.

Currie or his secretary underlined the last sentence. Smart appears to have been a clever promoter; the proposed gallery would include most of the leaders already painted for the Smithsonian collection. Like Sargent, Smart worked on both sides of the Atlantic. If Currie could not sit in Montreal in the spring, Smart could paint him that summer in London if he happened 


\section{The General Portrayed}

to be there. Smart sent photographs of portraits he already had done of Marshal Foch, General Pershing and Admiral Sims. These may have helped convince Currie to sit. Smart hoped to visit Currie soon. Like Sargent he needed a temporary studio; unlike Sargent he did not demand top-lights:

I have always to look out for a lofty room, with north lights preferably, to get a good result but expect it won't be difficult in Montreal or Ottawa. In Paris the Director of the Academy lent me one to paint Marshall Foch's portrait; two galleries in Washington offered me Studios to paint the President \& General Pershing \& the Art Association in Newport lent me their Studio for Admiral Sims, so I am bound to be treated well in Canada.

Smart arrived in Montreal in about mid-March and started Currie's portrait; the sittings took place somewhere at McGill. ${ }^{53} \mathrm{He}$ posed Currie at a rakish angle seldom seen in modern military portraits, knee on some battlefield rock (Figure 8). By June Smart was in England, building up clients. There was something about Currie which drew out confidences; Smart had not known him before the sittings yet afterwards he confided in Currie as a friend:

I have been hunting studios for weeks $\&$ have at last got, if not the finest, certainly one of the best in London - the House and Studio belonged to Sir J.J. Shannon R.A. \& I have bought the place from his widow... Well, I have started work, the first portrait being that of Mrs. Annie Besant. Next week or the following I hope to get the background of yours finished \& will then send you some photographs.

(The famous theosophist and educationalist Annie Besant (1847-1933) made a good catch; ten years later he would exhibit her portrait at the Royal Academy). Smart thanked Currie for the sittings and for sending him Leacock's recent book, My discovery of England, which amused him greatly. Smart believed Sir Robert Borden would be in England that summer and he hoped Currie would encourage him to sit for him (he did). Hoping to convince prominent military men to bave their portraits done for the collection, he would entice them by showing them photographs of the men he had already done. He asked Currie to lend his influence:
I think it would help if I had one or two letters from some I have painted. I wonder if you would mind writing me a short letter just to express your view of the portrait \& perhaps asking how I am getting on with the others for the collection? The one I think I will have the most bother with will be Clemenceau - I don't think he smiles very patiently upon artists! ...I. must tell you that Mrs. Besant spoke very highly of your portrait \& the second time she came, it was not on the easel $\&$ directly she entered she said "O Where is my General?"

Currie replied on 25 June 1924 with a useful letter wishing him success with bis project and asking to be remembered to any of my friends whose portraits he might paint. He was delighted that Smart was set up in England and added: "I sometimes feel that I left you so hurriedly at the last sitting that I did not properly express to you my complete satisfaction with what you had done in my case. " ${ }^{54}$ Although Smart's portrait was unconventional, Currie liked it.

Smart's gallery, whoever commissioned it, broke up by the 1930s. Trying to sell the collection piecemeal, he offered the Currie and Borden portraits to the only likely takers: Canadian institutions. From London in March 1934, he wrote to Eric Brown, Director of the National Gallery of Canada, giving the project's history:

Just after the war I was commissioned to paint the portraits of several of the leaders in the Great War; but owing to financial trouble the collection was not completed nor held intact. It was agreed that they might be if necessary individually hung in different Art Galleries or Public Buildings. Marshall Foch's portrait \& four others were taken over by the U.S.A. but the Canadian portraits were held back as they ought not to leave the Empire, but should if possible find their permanent home in Canada.

Candidly, Smart added that if he had foreseen Currie's death he would have tried to sell them earlier. He had exhibited the Currie and Borden portraits in about 1924 at the Montreal Musenm of Fine Arts before they went to the United States. He thought the National Gallery or the Canadian Archives would be the 


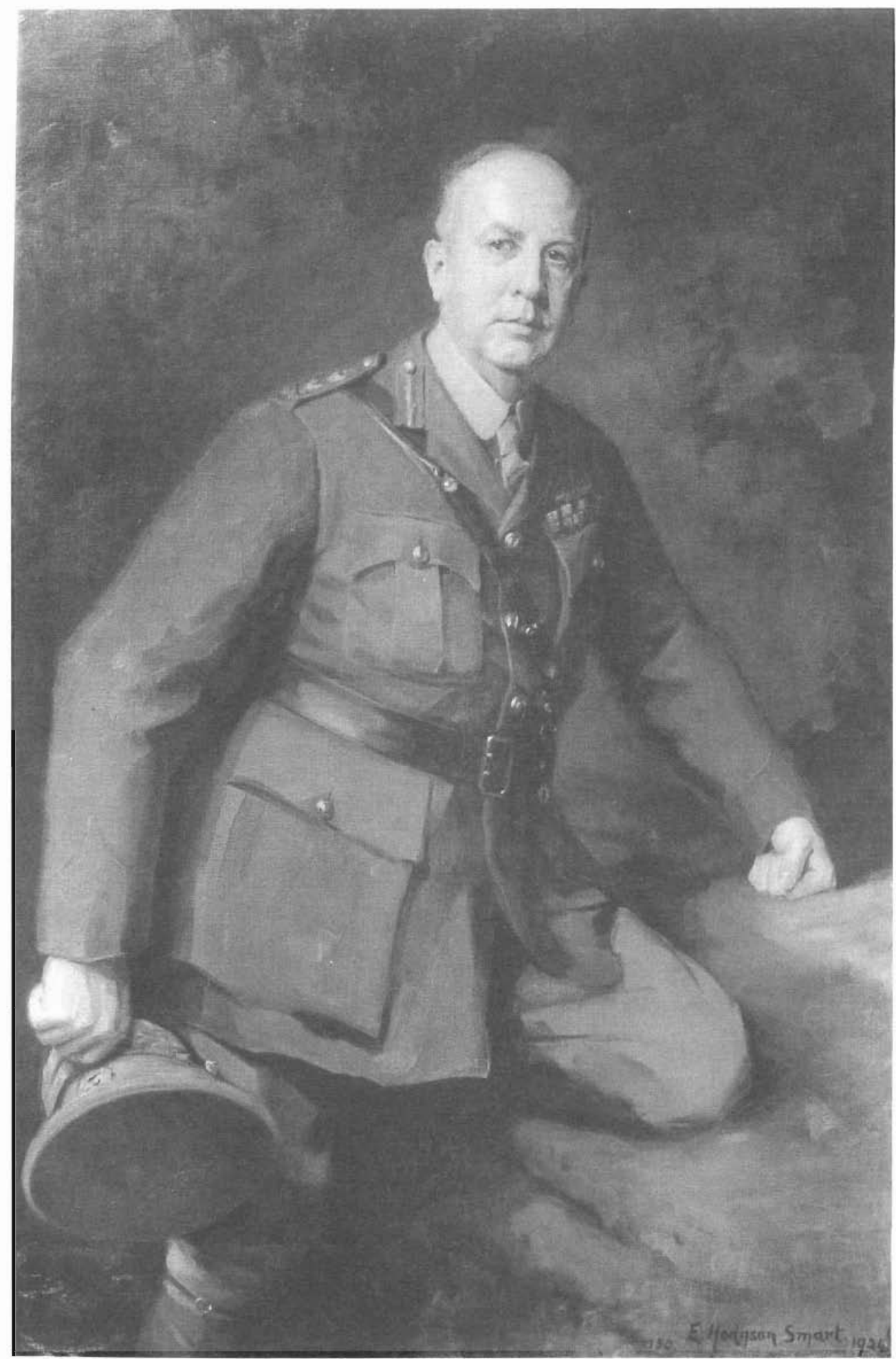

Figure 8. By E. Hodgson Smart. Oil on canvas, dimensions unknown, 1924. Location unknown. Photograph: McGill University Archives PRO28528. 


\section{The General Portrayed}

most suitable place for them. He asked the National Gallery to exhibit the portraits to "enable them to be seen \& then they could be judged upon their merits \& some decision arrived at as to their final destination." Brown replied that the Canadian War Memorials collection had portraits of Borden and Currie and suggested McGill might take the Currie and the Dominion Archives the Borden. McGill turned him down. Persistent, Smart approached Brown a year later; in August 1935 Brown repeated that the Orpen portrait of Currie sufficed and that Smart should try McGill or the Dominion Archives. In October 1935 Smart apparently sent photographs of the portraits to both institutions. Neither showed interest. In 1938 Smart made last-ditch efforts to sell the Canadian pair. In February, on Smart's behalf a publicity agent called the National Gallery's attention to the Borden portrait and was rebuffed. ${ }^{55}$ Smart visited Montreal in the fall and got the pair exhibited at the Montreal Museum of Fine Arts. They were reproduced in the Montreal Daily Star, 10 October 1938. In spite of his remarkable marketing efforts, his paintings, like Emily Warren's at the time, remained orphans. Recent enquiries to likely repositories have failed to turn up his portrait of Currie.

\section{ROBIN WATT, CA. 1927-1928 - SEEING AROUND CORNERS}

Robin Watt, M.C. (1896-1964) was born at Victoria, British Columbia. Currie probably knew the family from his Victoria days and visited Watt's mother in England. Educated in Victoria and at Sandhurst, Watt won the Military Cross and the Croix de Guerre, was mentioned in dispatches, wounded four times, and served as one of Currie's aides. In 1920 Watt began his art studies at the Slade School in London. Watt set up shop in Montreal around 1927. Currie must have preferred this soldier who became an artist to the artificial officer-artists of the war. Realising that portrait painting was a risky business, Currie reassured Mrs. Watt in December 1927 that "We see something of Robin and his wife and I think they are getting some commissions. My wife is, I know, arranging a tea when Robin, will give an exhibition." Soon Currie reported that Robin's exhibition, held in early February 1928 had gone well: "People were loud in their praises and, what is more to the point, the next day brought orders to keep Robin busy for a month at least. I think that Robin is very much bucked up." Currie added that Robin was not a very good salesman, "although I can well understand his diffidence and modesty." 56

When Watt finished a portrait he would keep it on his studio wall for a while: "If I get bored with it, then I know there is something wrong, and I try it again. "57 He argued that the camera could never replace painting: " A camera sees with only one eye, while the artist, with two, can see around corners." Watt must have had excellent rapport with his ex-chief and friend. The portrait proves the value of Watt's two eyes theory; it sees around corners to convey Currie's strong character (Figure 9). Strongly drawn in military colours, with war maps in its background, it makes a fitting tribute to Currie in the United Services Club - where Currie arrived in triumph, escorted by McGill students after winning the Cobourg libel suit in $1928 .^{58}$

\section{GHOSTS AND OTHER PORTRAITS}

Other Currie portraits may be mentioned briefly. Some are ghosts - referred to but not found. In September 1917 Currie recorded: "Had picture painted"; in December 1917 he noted: "sit for picture". The artist or artists may have been Emily Warren, sketching for "Canada's Tribute", Orpen sketching for his projected group, Richard Jack or perhaps war artist Charles Sims (1873-1928). Currie definitely saw the latter two at this time. On 15 December 1917 he had "the artist Sims to lunch and dinner"; on 30 December 1917 he visited Jack's studio. ${ }^{59}$ Around 1918 McGill architect Percy Nobbs made an on the spot sketch of Currie being congratulated by General Haig; he gave it to Currie explaining "You are the man in the "Burbery" and Haig is in the middle of the picture. "60 Inglis Sheldon-Williams sketched Currie and his staff crossing the Rhine at Bonn in December 1918, perhaps for his large work "Canadians Arriving on the Rhine". In 1947 the Sheldon-Williams estate offered and sent a number of works to the National Gallery of Canada; they included a pencil sketch of General Currie crossing the Rhine at Bonn. The National Gallery's trustees decided "we don't need it" [neglected collections seldom need additions] and the works were returned in 1949. ${ }^{61}$ In 1921 the publisher John Lane asked Currie to sit for Vernon Hill for a book of drawings and the 
The General Portrayed

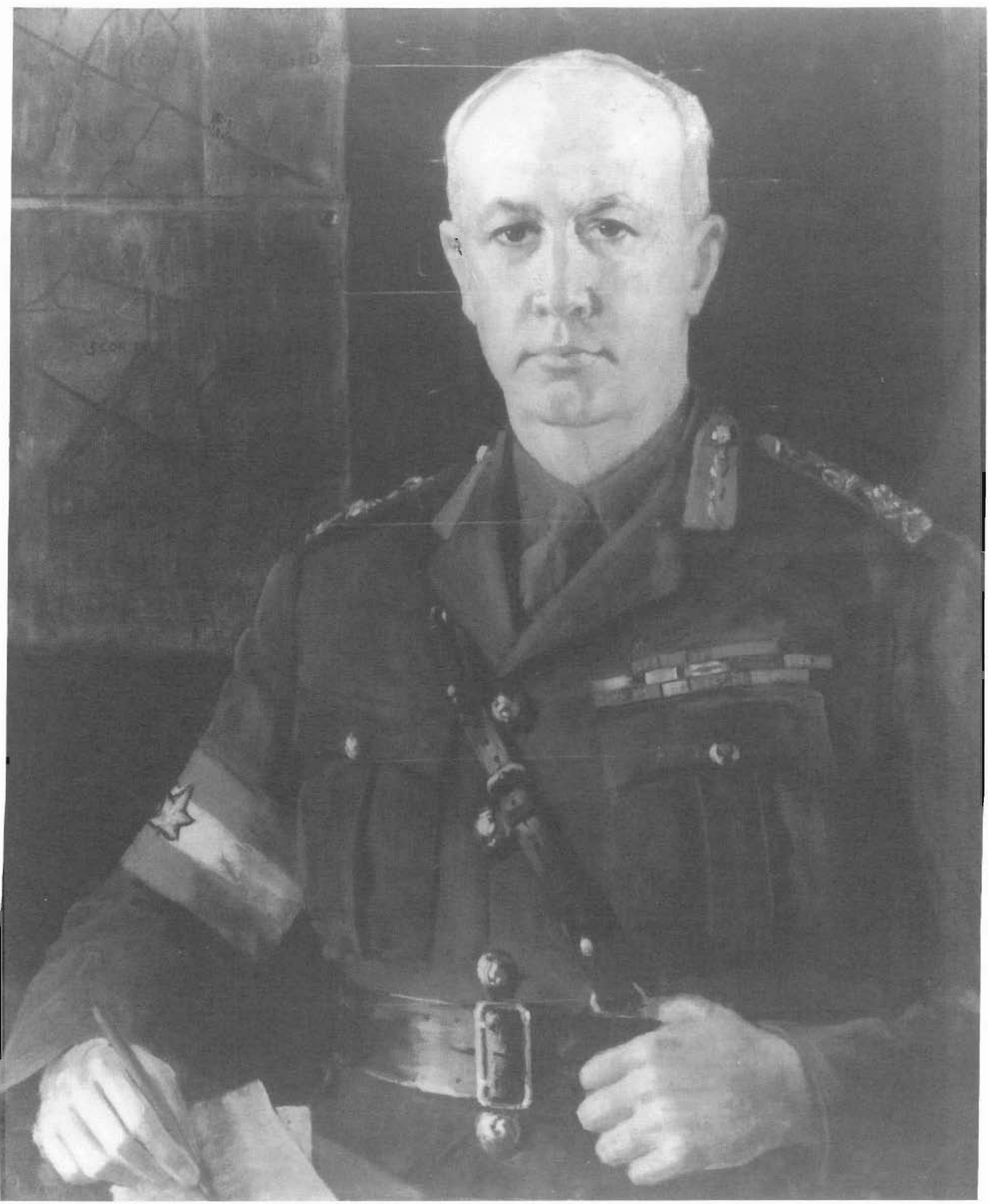

Figure 9. By Robin Watt. Oil on canvas, 91 x 76 cm., ca. 1927-1930. United Services Club, Montreal. 


\section{The General Portrayed}

Raines Company of Canada and England wanted to reproduce his photograph in oils; it is unclear if anything resulted. In 1928, an unemployed Californian sent Currie a portrait, presumably made from a photograph. ${ }^{62}$ All these works, like the Hodgson Smart portrait, remain unlocated.

Some portraits were ephemeral: Arthur Lismer sketched cartoons of McGill's Principals on the plaster walls of Dawson Hall at McGill before they were renovated in 1947. Paul McCullagh photographed them before they were destroyed: Currie stands hands on hips, facing the shells of military or academic battle, wearing an academic gown over his uniform. A cartoon by A.G. Racey of Currie handing out diplomas appeared in the McGill student annual in 1924. When Currie visited India in 1931, a newspaper published a sketch of him; it bears little resemblance to Currie, with its aquiline nose and pointed chin. ${ }^{63}$

Not all of Currie portraits were in uniform. Katbleen Shackleton sketched his head in charcoal, probably in the late 1920s (location unknown); and an official portrait by B. Gordon in Principal's robes hangs in McGill's Redpath Hall. Principal F.C. James refers to a portrait in academic gown by "Maclntosh" (location unknown). ${ }^{64}$ Currie has continued to inspire portraits. In about 1969 Alison MacNeil sculpted a bust of Currie for the Currie Hall at the Royal Military Academy at Kingston. H.J. Ariss drew a striking pastel that captures Currie's determined look, reminiscent of Currie's favourite photograph by Swaine of London. ${ }^{65}$

\section{EMILY WARREN, CA. 1917-1920 - A FAITHFUL PORTRAYL}

What did Currie think about art? He realized the power of images: they formed part of the multifaceted technology of war which he mastered instinctively. $\mathrm{He}$ attended the various war pictures exhibitions and even gave a session to a "moving picture artist." ${ }^{166} \mathrm{He}$ constantly responded to requests for his photograph (Figure 10). ${ }^{67}$ When the Royal Military College planned its Assembly Hall as a tribute to the Canadian Corps, Principal Currie enlisted McGill architecture professors Nobbs and Traquair to design and decorate it. $^{68}$
Currie's attitudes towards art came out in his defense of Emily Warren's paintings. Emily Warren (18691956) grew up in England; at fourteen she found a mentor in Jobn Ruskin. In 1917 she was painting in Westminster Abbey when men from a Canadian regiment deposited their colours at Wolfe's monument before going to the front. Moved by this and the recent death at Vimy Ridge of a Canadian cousin, Major Jack Sweet, she resolved to paint the scene retrospectively. She was encouraged by General Currie (who had been Sweet's friend). The War Office pressed her to expand her subject to include the seventy-seven commanders and fifty-two regimental colours of the Canadian Expeditionary Force. She painted two canvasses (11.5 by 6 feet), of Canadian officers with their colours in the Abbey, called "Canada's Tribute," She sketched the officers from life in short sittings, tracking them down in their camps and London hotels. Warren wrote Currie that her group of Canadian heroes would not be complete without him; she wanted to make a colour sketch of him. If this was impossible, she would need a photograph, in profile. She enclosed a card showing Currie's position in the paintings. An aide attached a memo to her letter: "Remind Corps Commander that he owes this lady a picture". ${ }^{69}$ Currie must have complied; he is the central figure in both canvasses. At war's end the paintings lacked some regimental colours and portraits. Currie (and probably Robert Borden) advised Warren to take them to Canada. She had hopes but no commitment that the Dominion government would buy the paintings.

"Canada's Tribute" epitomized a heroic, romantic view of war unpopular with critics and curators. In a sacramental, patriotic atmosphere, the light comes down through the Abbey's arches to illuminate the upturned faces and draped colours offered at the altar of ancient glory (Figure 11). She painted realistically; the officers are recognisable. To modernists like Paul Konody, art advisor for the Canadian War Memorials, "Canada's Tribute" seemed old-fashioned and sentimental. Warren herself said the paintings were meant to be symbolic works, of historical rather than artistic value ${ }^{70}$ By late 1920 it seemed evident that they would not be bought for the National Gallery of Canada. Yet they had been exhibited and many war veterans liked them. The Ottawa branch of Great War Veterans Association urged the government to pay Warren's (negotiable) price of $\$ 10,000$. It was a classic case of 


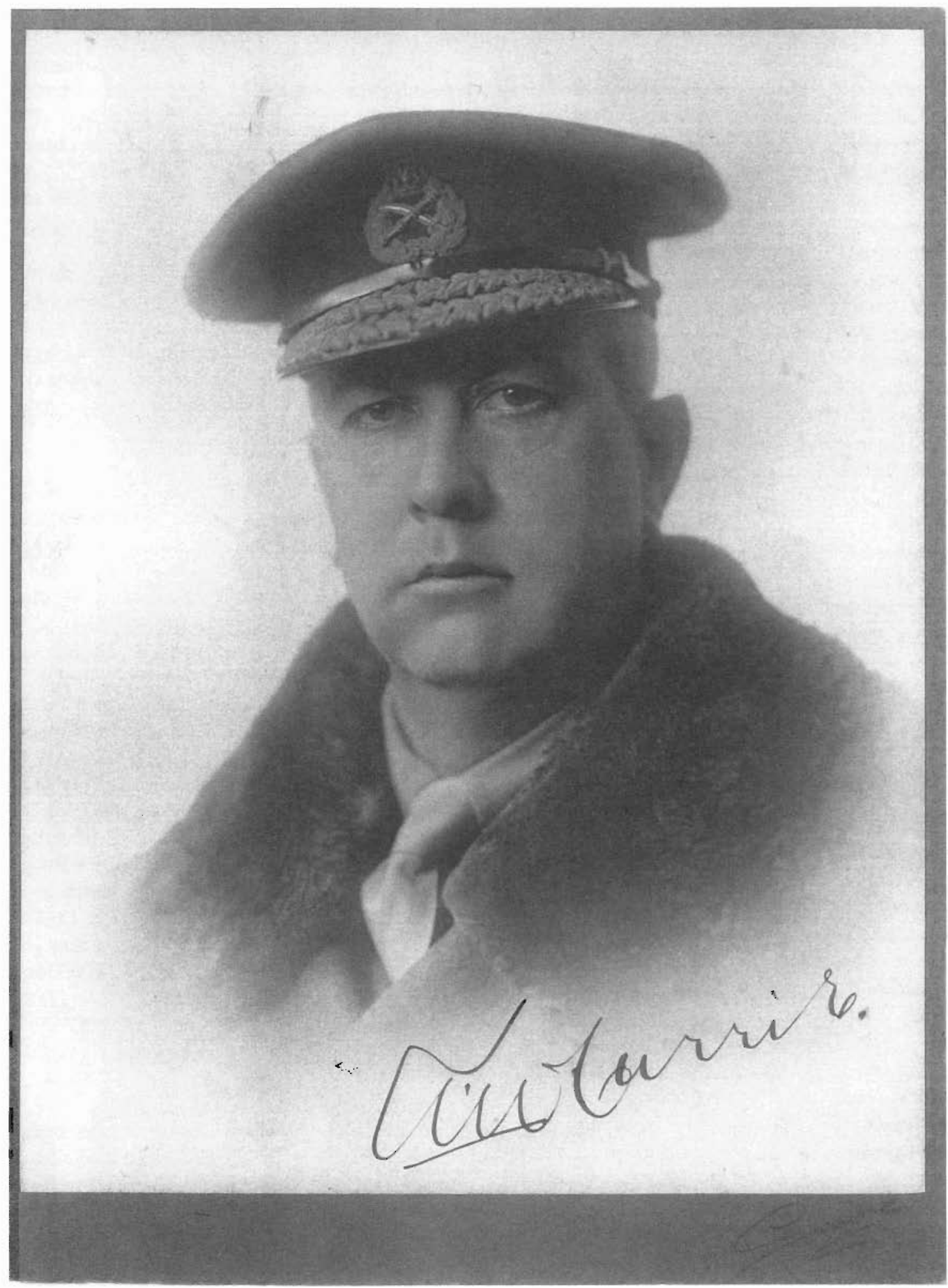

Figure 10. Photograph by Swaine of London, ca. 1918. 


\section{The General Portrayed}

public taste versus the art experts. ${ }^{71}$ Currie quietly supported Warren; in November 1920, he tried to convince F.B. McCurdy, Minister of Public Works, that the paintings had historical value and should be bought, unlike much "freakish" war art. ${ }^{72}$ He probably felt some responsibility for Warren's plight, having encouraged her to bring the paintings to Canada.

Charles Bowman, editor of the Ottawa Journal campaigned for the paintings. He asked Currie to give his views publicly. Currie replied in early December 1920 that he wanted to avoid controversy with the government (Sam Hughes's continuing criticism of his wartime strategy gave him problems enough). On the understanding that his letter would remain personal and unpublished, Currie praised Warren for her accuracy and complained that many of the Canadian War Memorial pictures had been armchair productions:

I may say I know Miss Warren's pictures very well indeed, though my ignorance of painting does not justify me in expressing any opinion as to their artistic value. What I do know is that she was most energetic and conscientious in having a faithful portrayal of the subject. The men, and there are in the pictures a great many, as you know, were painted from life....I do not believe that there is amongst all the Canadian War pictures one which is more exact in detail, and I do know that many of the pictures which Canada has paid for have been painted in their studios by artists who, in the painting, give no evidence of ever seeing the place or the situation or the circumstance which they seek to depict. Many of the pictures which Canada has bought, and I presume paid for, are what the ordinary uneducated person like myself regard as freak pictures. I have seen an exbibition of these pictures and also I spent all the months in France that Canadian troops were there. I never saw anything which by the wildest stretch of the imagination appears to be what some of these artists bave painted. I frankly admit that possibly it is my ignorance of Art that leads me to make such a statement, but I submit that these pictures [Warren's] are intended to be of interest to other ignorant people like myself. They are not merely for the so-called artists to view and enjoy.
He added that Warren's portrayals were true to life, that he could not understand "why the Government refused to consider Miss Warren's painting when they have been saddled by some of the freaks I have referred to above." He concluded "The workings of the War Memorial Board and the War Records Organizations would make a very interesting study. ${ }^{173}$ In short, though disclaiming expertise, Currie liked traditional representational art, accurate in detail, with a strong uplifting message.

In 1923 Currie had to refuse Warren's offer to sell the paintings to McGill - the University had no funds for such purposes - but he tried to help Warren fiad them temporary homes. In March 1924 he asked General Macdonell if the Royal Military College could take them for a while:

I feel sorry for the old lady. She bas put a wonderful amount of work into the pictures....I am quite sure if she had made Sam Hughes the central figure that the government would have purchased them long ago. I think, Mac, that you might store them somewhere, but in your agreement to do it be very careful not to give Miss Warren any hope that the R.M.C. will become their permanent home. ${ }^{74}$

Oddly enough, the paintings ended up at R.M.C. in the Currie Memorial Hall no less. They took a long time to get there. They appear to have hung in Moyse Hall, McGill University in the 1930s (the exact dates are uncertain), where they suffered damage from radiators. Warren crossed the Atlantic in 1940 to rescue and restore the paintings. From 1941 to 1948, they hung in the Hall of Fame in Parliament. Then the Department of Defense paid Warren $\$ 5000$ for the pair and installed them at R.M.C. ${ }^{75}$

\section{THE CURRIE PORTRAITS AND MCGILL}

Since Currie served as Principal, it is not surprising that McGill owns or was offered several of the works mentioned here. McGill was given the Kennington portrait and the little Sargent sketch; the Jack portrait was purchased. After Currie's death, McGill's Governors turned down Smart's offer of his Currie portrait at $\$ 2000$. At the same time, in 1934 , the 


\section{The General Portrayed}

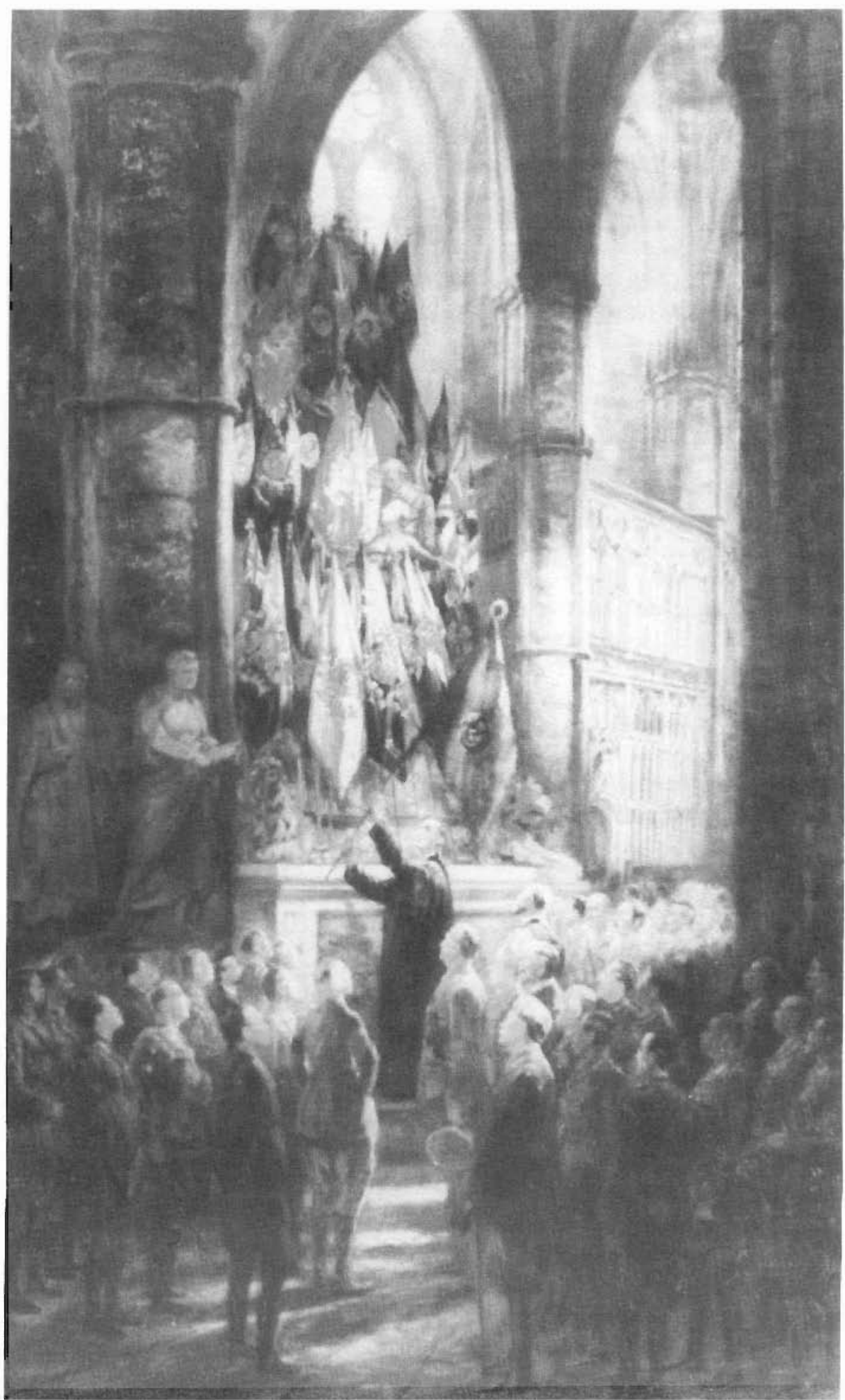

Figure 11. Canada's Tribute (one of a pair) by Emily Warren. Oil on canvas, $335 \times 183 \mathrm{~cm}$., ca. 1918. Royal Military College, Kingston, Ontario. 


\section{The General Portrayed}

financially-pressed board tried without success to obtain the Orpen portrait free from the Dominion Government - little knowing how Currie had disliked it. The Governors also refused an offer from Emily Warren to sell one or both of the "Canada's Tribute" groups, which at some point had been lent to McGill. During the Depression, McGill simply could not justify buying portraits. ${ }^{76}$ Indeed, the difficulties which Warren and Smart experienced in selling their portraits of war leaders show that interest in war art declined as time passed.

\section{$* * * * * * * * * * * * * *$}

Currie's military portraits were a microcosm of the effort to memorialize the war and its leaders. In the age of photography, oil portraits and bronze sculptures maintained their aesthetic precedence. War artists tried to surpass the mere reality of photographs to capture higher truths that would interpret the war for all time. Every town had its war memorial monument: obelisks, tablets or angels bearing anonymous soldiers to Valhalla. Generals had portraits. The soldiers' monuments survive in town centres; the portraits hang in museums, often in storage.

Currie gladly allowed himself to be painted - not for vanity but because he symbolized Canada's war effort. Ironically, the only portrait Currie disliked that by Orpen - now memorializes him at the National War Museum and at the Royal Military College, Kingston. He got on well with his mixed bag of painters. The four who wrote to him or about him after the sittings (Warren, DeCamp, Kennington, and Smart) obviously liked him; Currie understood people and won them over throughout his career. Currie's portraits show subtle differences in mood and physical appearance; taken all together they capture his psychology - blunt, friendly, brave, determined, and intelligent, with something reserved which Sargent caught. This article has examined the art of interpreting appearance. When we look at portraits, we read character from appearance yet search for the character hidden beneath appearance; a true portrait of Arthur Currie needs not only paint but words - such as the pen sketches about his looks and character by his brother officers, quoted earlier. Two McGill friends, Leacock and Currie's secretary Dorothy McMurray, saw much of him on Saturday, 4 November 1933, the day before his strokes. Their memories of his McGill routine and his last day at work are a kind of portrait.

McMurray recalled that he came to work as usual. He was happy and told her how well he felt: "Surely I have ten good years yet." He had cleared up all his work for the term, including the previous year's annual report. McMurray noted: "Strangely enough the day he left the office for the last time, his desk and work at the University were more completely clear than at any other period I know of." A few weeks before, he had overseen the laying of the cornerstone of the Montreal Neurological Institute, a high point in his Principalship. Currie had used the phrase "His life had come full circle" at a recent memorial service. Now his own life had come full circle as well, wrote McMurray. His work had been completed: "He had fought and conquered in the war. He had studied and mastered the so called "mysteries" of education.... he seemed to me to hold in the hollow of his hand all the intricate threads of the University loom...."

Currie left his office and lunched at the University Club with Leacock and others; afterwards they went to the McGill football game. Currie loved football and had recently congratulated coach Frank Shaughnessy on the team's wins. Now he watched McGill beat Queen's, the first home win over this old rival since 1927. The jubilant students raided theatres and invaded the Mount Royal Hotel; fifty constables kept them at bay. Currie went home to work on a Remembrance Day talk. He had a stroke the next day, went to hospital, and slowly recovered, according to doctors' bulletins, until he died on 30 November 1933 and had the most elaborate funeral in Canadian history. Leacock wrote a famous tribute, portraying him in his office:

ready and accessible to us all. Beside him was his pipe with plenty of strong tobacco and plenty of strong language to keep it burning....He thought no more of a plutocrat than of a ninepin.... Never was there a man so deeply religious in the real meaning of the word. He lived, in peace as in war, with the consciousness of the imminence of death....His dusty, shabby professors were always a sort of mystery to him.... We never had the place in his heart that he kept for his generals. 
Yet to those of his McGill staff experiencing dark hours, he was "beyond words". He had

a tenderness of sympathy, an affection for those in distress that no language can present and that no gratitude can repay.

\section{ACKNOWLEDGEMENTS}

I owe thanks above all to Cindy Campbell, Archivist, National Gallery of Canada. I am indebted to Dr. Richard Virr, Associate Editor, Fontanus, for advice in developing this topic and to many archivists, librarians, historians, and curators of art: Carol Wiens, Librarian, Montreal Neurological Institute/ Hospital; Gary Tynski, Rare Books and Special Collections, McGill; Irena Murray and Marilyn Berger and staff, BlackaderLauterman Library, McGill; Bruce Dolphin and Jane Kingsland, McGill University Archives; Silvia Tark and Eric Vanasse, Montreal Museum of Fine Arts; Bruce Russell (Research Fellow), National Gallery of Canada; Jim Burant, Kate O'Rourke, Janet Murray, Sarah Montgomery, and the staff of the National Archives of Canada; Laura Brandon, Canadian War Museum; J.R. McKenzie, Royal Military College of Canada, Kingston; A.J.M. Hyatt, History Dept., University of Western Ontario; Alan Singer, Montreal; Betsy Anderson and Richard Murray, National Museum of American Art, Smithsonian Institution; Robert Stewart, National Portrait Gallery, Smithsonian Institution; Patricia Krohn, Cleveland Museum of Art; Carrie Reborra, Metropolitan Museum of Art, New York; Miriam Stewart and Timothy Burgard, Harvard University Art Museums; Tim Moreton and Jill Springall, National Portrait Gallery, London; Jennifer Wood, Imperial War Museum, London; and finally, the owner of the oil portrait by Sargent.

For permission to reproduce portraits, I am indebted to the United Services Club, Montreal; the National War Museum, Ottawa; the National Portrait Gallery, London; and the Smithsonian Institution, Washington. 


\section{The General Portrayed}

\section{Notes}

Abbreviations used in endnotes:

$\begin{array}{ll}\text { C } & \text { Container } \\ \text { CP } & \text { Sir Arthur Chrrie Papers, MG30 } \\ & \text { E100 (at NAC) } \\ \text { MG } & \text { Manuscript Group } \\ \text { MUA } & \text { McGill University Archives } \\ \text { MUA, RG2 } & \text { Records of the Principal, MUA. } \\ \text { MUA, RG4 } & \text { Records of the Board of Governors, } \\ & \text { MUA. } \\ \text { NAC } & \text { National Archives of Canada } \\ \text { NGCA } & \text { National Gallery of Canada Archives } \\ \text { RG } & \text { Record Group } \\ \text { UP } & \text { Hugh Urquhart Papers, MG 4027 (at } \\ & \text { MUA) }\end{array}$

1. Currie's records are interfiled with those of Principals A.E. Morgan (1935-1937) and L.W. Douglas (1937-1939). Currie's records were maintained by his secretary Margaret Chesley and her successor Margaret McMurray. In 1993 the Archives received a federal grant (under the Conservation Plan for Canadian Archival Records) to microfilm Principals' External Correspondence (MUA, RG2, C38-C51) for the years 1919 to 1940 , for the purposes of preservation and diffusion. Most of Currie's correspondence with artists comes from MUA, RG2, C38, file 152: "Photographs 1920-1927" (the bulk of the letters in the file are requests for photographs of Currie). Principal Currie corresponded with external organisations and individuals about veterans' causes, world disarmament, imperial conferences, charities, politics and many other topics. People wrote to Currie as former Commander, as McGill Principal, as a father figure, and as the de facto leader of English-speaking Montreal. Politicians, veterans, businessmen, social reformers, inventors, parents and patients in asylums asked his advice or sounded off to him. The MUA also holds some of Currie's private papers and speeches: MG 1030. On Currie as Principal, see Stanley B. Frost, McGill University (2 vols. Montreal 1980-1984). In addition to the biographies cited in note 3 , works using Currie's records as Principal include Margaret Gillett, We walked very warily (Montreal 1981); and Marlene Shore, The science of social redemption: McGill, the Chicago School, and the origins of social research in
Canada (Toronto 1987). The Sir Arthur Currie Papers (MG30 E100) at the National Archives of Canada contain diaries, correspondence and much on veterans' affairs; there is considerable subject overlap with the Principal's External Correspondence at McGill.

2. NAC, CP, Private diary, 3 May 1918; a transcript of the diary is in the Urquhart Papers, MUA, UP.

3. A.J.M. Hyatt, General Sir Arthur Currie: a military biography (Toronto, 1987) is a definitive military biography. For greater coverage of the McGill years see H.M. Urquhart, Arthur Currie (Toronto, 1950) and Daniel G. Dancocks' lively Sir Anthur Currie (Agincourt, Ontario, 1985). For the Canadian role in the war, see Desmond Morton and J.L. Granatstein, Marching to Armageddon: Canadians and the Great War 1914-1919 (Toronto, 1989).

4. Robert Shipley, To mark our place: a history of Canadian war memorials (Toronto, 1987), 161.

5. MUA, UP, "Correspondence re Currie biography", Interview with General Loomis, n.d; Herbert Molson to Urquhart, 12 June 1936.

6. Walter Abell, "War records for the Canadian Army", Canadian Art, vol. 1, no. 2 (Dec.-Jan., 19431944), 43-46, 85 .

7. Maria Tippett, Art at the service of war: Canada, art, and the Great War (Toronto, 1984), 26. This authoritative book reproduces a selection of war art.

8. Tippett, Art at the service of war, passim; P.G. Konody, "Canadian War Memorials Number", Colour (Sept. 1918), 25-41. Paul Konody also published $A r t$ and war: Canadian war memorials (London, 1919), which reproduces numerous works done for the Canadian War Memorials Fund. Canadian and British war art was covered frequently in The Studio, 19171919.

9. Barker Fairley, "Canadian war pictures", The Canadian Magazine, vol. 54, no. 1 (Nov, 1919), 2-11.

10. Hector Charlesworth, "The National Gallery a national reproach", Saturday Night (9 Dec. 1922), 3. 


\section{The General Portrayed}

11. H. Robertson, A terrible Beauty: the art of Canada at war (Ottawa, 1977), 15. See also Tippett, Art at the service of war, 112; R.F. Wodehouse, "The Canadian War Memorials Collection at Ottawa", Studio International, vol. 176, no. 906 (Dec. 1968), 234-236; R.F. Wodehouse, $A$ check list of the war collections of World War I, 1914-1918 and World War II, 1939-1945, (Ottawa, 1968); Robert Shipley, To mark our place: a history of Canadian war memorials (Toronto, 1987).

12. Tippett, Art at the service of war, 23-30. See Colin S. Macdonald, comp., A dictionary of Canadian Artists (7 vols. 1968-1990), ii. 518-520.

13. MUA, UP, transcript of NAC, CP, Private diary, 30 Dec. 1917; 9 Mar. 1919; 23 Mar. 1919; 9 Apr. 1919.

14. Other donors at a ceremony at British Columbia House, London, were General Clark, Colonel Tudor, and Majors Fiske and Herridge: NAC, CP, Private diary, 9 April 1919. Jack told Currie that after some slight changes he would send it to Currie's mother in Canada. When by March 1920 the portrait had not arrived, Currie wrote to Loomis who promised to look into it: NAC, CP, Currie to Loomis, 2 Mar. 1920; Loomis to Currie, 10 Mar. 1920.

15. MUA, RG2, C228, file 1980: "Lady Currie Donations 1948", Principal Cyril James to Lady Currie, 27 Sept. 1947; MUA, RG4, C191, file 104, "Lady Currie", Lady Currie to Chancellor Bertie Gardner, 11 June 1957.

16. John Singer Sargent's note that he was six feet three may be the most dependable figure. See Hyatt, General Sir Arthur Currie, 23; Dancocks, Sir Arthur Currie, 143. The latter put Currie's height at 6 feet four inches and his wartime weight at 250 pounds.

17. NGCA, Artist's file: Richard Jack. The file refers to sketches of Currie and others which Jack planned to give to the subjects as souvenirs. Jack also painted Currie's friend Stephen Leacock; see the Montreal Gazette, 13 Jan. 1945.

18. MUA, UP, "Correspondence re Currie biography" (copies), "Impressions of A.C. by Brig. Gen. E.S. Hoare-Nairne", p. 16. Currie's first biographer,
Urquhart wrote to many officers in the later 1930 s to get their first hand impressions of General Currie. Among other things, Urquhart asked for impressions of Currie's appearance. His notes in the University Archives prove the continuing value of biographers' papers as raw material for further investigation of their subjects.

19. MUA, UP, "Correspondence re Currie biography", Colonel Crerar, "Notes on General Sir Arthur Currie" (copy), n.d.

20. MUA, UP, "Correspondence re Currie biography", Frith to Urquhart, 1 Jan. 1937. Frith admired Currie for firmness in upholding a sentence of execution for desertion, despite the clemency pleas of Canon F.G. Scott: Dancocks, Sir Arthur Currie, 67.

21. Pointed out by Hyatt, General Sir Arthur Currie, 23.

22. Bruce Arnold, Orpen: mirror to an age (London, 1982), 330-331. See also P.G. Konody and Sidney Dark, Sir William Orpen: artist and man (London, 1932), 253-257 and NGCA, 5.41.0, "Sir Edmund Walker".

23. NAC, CP, "Beaverbrook", Currie to Beaverbrook, 27 Jan. 1918; Beaverbrook to Currie, 6 Feb., 1918.

24. MUA, UP, transcript of NAC, CP, Private diary, 17, 18, 19, and 22, February 1919, 3 March 1919.

25. Arnold, Orpen, 333-337; 377-380; Konody and Dark, Sir William Orpen, 168-171.

26. MUA, RG2, C38, file 152: "Photographs 19201927 ", Currie to Edmund Walker, 5 Mar. 1924; Walker to Currie, 10 Mar. 1924. The portrait is listed in the exhibition's catalogue: The National Gallery of Canada, Second exhibition of Canadian war memorials, January 18th to April 30th, Ottawa, 1924, 12. The portrait had been displayed previously in the $1923 \mathrm{War}$ Memorials Exhibition.

27. NAC, CP, "Bro-By", JAC to Eric Brown, 6 June 1929. A copy sent to Currie was unsigned but the typist's initialled subscription indicated it typed for "JAC": J.A. Clark is the only MP with these initials: The Canadian Parliamentary Guide (1929), 59, 127. 
28. Royal Military College of Canada, Programme for the opening of the Sir Arthur Currie Hall, 1922. Mitchell Kryzanowski, Currie Hall: memorial to the Canadian Corps (Kingston, 1989) gives an illustrated history of the Hall and reproduces the Rawbon copy, 14; NGCA, Artist's file: Rawbon.

29. Dictionary of National Biography, 1951-1960, 573574; Tippett, Art at the service of war, 67-68.

30. MUA, UP, transcript of NAC, CP, Private diary, 11 Dec. 1918.

31. The portrait and the note (both framed) are in the Faculty Club, McGill University, the gift of Frederick N. Southam, May 1938.

32. Who was who in America, vol. 1 (1897-1942), 309; Trevor J. Fairbrother, The Bostonians: painters of an elegant age, 1870-1930 (Museum of Fine Arts, Boston, 1986), 205-206; Ten American painters: a loan exhibition for the benefit of the Fellowship Fund in Art History, City University of New York (Spanierman Gallery, New York, 1990), 93-97. The name appears as both DeCamp and De Camp; the signature in Currie's papers appears to be DeCamp.

33. Frederick Platt, "The war portraits", Antiques (July 1984), 142-153; The National Art Committee, Exhibition of war portraits: January 18 to February 11, 1921, Metropolitan Museum of Art, New York, 1921.

34. NAC, CP, "P-R", Herbert Pratt to Currie, 29 Sept. 1919; Currie to Pratt, 14 Oct. 1919; Pratt to Currie, 18 May 1920; Currie to Pratt, 21 May 1920; Pratt to Currie, 4 June 1920; Currie to Pratt, 7 June 1920. NAC, CP, "S-Z", Currie to Wiles, 7 May 1920; Wiles to Currie,15 May 1920.

35. MUA, RG2, C38, file 152, "Photographs, 19201927", DeCamp to Currie, 2 Dec. 1920, 10 Dec. 1920; Currie to DeCamp, 13 Dec. 1920.

36. Platt, "The war portraits", 143; The National Art Committee, Exhibition of war portraits.

37. The project is discussed in William H. Downes, John S. Sargent (Boston, 1925), 78-79, 256-257; Evan Charteris, John Sargent (New York, 1927), 217-219;
Charles M. Mount, John Singer Sargent: a biography (New York, 1955), 363-364, 376-377, 388; and Stanley Olson, John Singer Sargent: his portrait (London, 1986), 257-267. The painting is reproduced in Carter Ratcliff, John Singer Sargent (New York, 1982), 206.

38. Charteris, Sargent, 217-218.

39. Mount, Sargent, 377; William Watson, Retrospective: recollections of a Montreal art dealer (Toronto, 1974), 68; Arnold, Orpen, 378.

40. MUA, RG 2, C38, file 152, "Photographs, 19201927", James D. Milner to Arthur Currie, 27 Aug. 1920; Currie to Milner, 20 Sept. 1920: Currie to Sargent, 20 Sept. 1920; Sargent to Currie, 2 Oct. 1920; Sargent to Currie, 9 May 1921; Currie to Sargent, 16 May 1921; Sargent to Currie, 19 May 1921. Currie had been appointed a Director of the Bank of Montreal when he became Principal; the remuneration was $\$ 3000$ -\$4000 a year: Dancocks, Sir Arthur Currie, 207.

41. The auctions were on 24 and 27 July 1925: Catalogue of pictures and water colour drawings by J.S. Sargent, Christie, Manson and Woods (London, 1925); see H.C. Marillier, "Christie's" 1766 to 1925 (London, 1926), 231-233.

42. NAC, CP, "Cap-Cur", Currie to Cowie, 8 April 1927; MUA, RG40 (Records of the University Libraries), C18, "Sir Arthur Currie 1927", Memorandum re sketch of Principal, 11 April 1927.

43. Richard Pennington's catalogue of paintings at McGill (1956) listed a Sargent pencil sketch. Following this clue, the sketch was found by Gary Tynski, Curator, in the prints and drawings of the McGill Rare Book Department. Pennington's catalogue incorporates and amends a catalogue made in 1954 by Sidney and Mary Carter: both are in MUA, RG4, C191, file 76, "Catalogue of paintings 1954-1956".

44. Reproduced in Ratcliff, John Singer Sargent, 206.

45. Downes, John S. Sargent, 256-257.

46. Charteris, John Sargent, 218.

47. Simon Schama, Dead certainties (New York, 1991), section I: "The many deaths of General Wolfe". 


\section{The General Portrayed}

48. Reproduced in Sir James Caw, Sir James Guthrie (London, 1932), facing 176.

49. Charteris, Sargent, 217-218.

50. MUA, UP, "Correspondence" (unsorted), Leacock to Urqubart, 29 Dec. 1937.

51. A.Y. Jackson, "A record of total war", Canadian Art, vol. 3, no. 4 (July 1946), 150-151. The heroic theme, although often ridiculed, survived in sculpture more easily than painting. The War Memorial in Ottawa is an example.

52. Who was who in American art, ed. H. Falk (1985), 574; Who was who 1941-1950 (London, 1964), 1064.

53. NGCA, 5.41.0, "Canadian War Art: offer for purchase / presentation of war art", Smart to Brown, 23 March 1934.

54. MUA, RG2, C38, file 152, "Photographs 19201927", E. Hodgson Smart to Sir Arthur Currie, 26 Feb. 1924; Smart to Currie, 7 March 1924; Smart to Currie, 11 June 1924; Currie to Smart, 25 June 1924.

55. NGCA, 5.41.0, Canadian War Art: "Offer for purchase / presentation of war art (N-Z)", Smart to Brown, 23 March 1934; Brown to Smart, 7 May 1934; Brown to Smart, 14 August 1935; Smart to Brown, 3 October 1935; F. Don Endress to Brown, 24 Feb. 1938; Brown to Endress, 8 Mar. 1938.

56. MUA, RG2, C51, "Was-Wat, 1922-1928", Currie to M.R. (Mrs. Alfred) Watt, 21 Dec. 1927, 15 Feb. 1928.

57. Obituary, Montreal Star, 11 Sept. 1964; Montreal Gazette, 27 Dec. 1948. See NGCA, Artist's file, Robin Watt. Watt and his wife Dodie are recalled in George Melly, Rum, bum and concertina (London, 1989), 51-55.

58. The portrait was presented to the United Services Club, Montreal by Geoffrey O. Merrill, a Montreal insurance broker and war veteran, in memory of Major P. Stanley, D.S.O., President of the Club, 1925-1926.
59. MUA, UP, transcript NAC, CP, Private diary, 18 Sept.1917, 15 and 30 Dec. 1917. Sims did a memorial panel in the Parliament of Canada.

60. NAC, CP, General correspondence, 1919. I-P: Nobbs to Currie, 25 Aug. 1919.

61. NGCA, S.41-0, Sir Edmund Walker, "Offers N-Z" (docket: Sheldon-Williams). See Tippett, Art at the service of war, 67.

62. The Hill drawings are referred to in MUA, RG2, C55, file 800, "MacMillan, history of McGill", Lane to Currie, 19 Sept. 1921. For Raines company: see NAC, CP, (Vol. 5, file 16) "S-Z". MUA, RG2, c47, file 489: "MAS-MD 1919-1938", letter, J.F. Mathews to Currie, 15 June 1928.

63. The Lismer cartoon is MUA photograph PR024709. The cartoon is in Old McGill, 1924, 163. The Far East clipping is in MG30 E100, vol. 25, file 75: "India, 1930-1931, 1933."

64. MUA holds a negative of a sketch by Kathleen Shackleton ca. 1927 (Pictorial Collection, no. 114); the sketch was published in Old McGill, 1928, 12. The Currie portrait is not among Shackleton's charcoal portraits in the Blackader-Lauterman rare book collection, folio W10.S524. MUA, RG2, C228, file 1980, "Lady Currie Donations 1948", F.C. James to Lady Currie, 27 Sept. 1948.

65. The bust work is reproduced in Kryanowski, Currie Hall, 55, the Ariss portrait in Hyatt, General Sir Arthur Currie, xxii.

66. MUA, UP, transcript of NAC, CP, Private diary, 22 Nov. 1917, 24 Jan. 1918.

67. His favourite was probably by Swaine of London, ca. 1918. NAC, CP, (Vol. 5, file 16), General correspondence, "S-Z", contains Currie's order to Swaine's for more prints (Swaine number 31383-G.).

68. Kryzanowski, Currie Hall, 5-11.

69. NAC, CP, General Correspondence, "S-Z", letter Warren to Currie 22 Nov. 1917? 


\section{The General Portrayed}

70. Constance McRae, The light must be perfect: the life and art of Emily Warren (Toronto, 1981), 38-43, 58-65, 119-124, and passim.

71. Constance McRae, "A neglected Canadian artist: Emily Warren", Canadian Collector (Nov./Dec. 1977), 45-49. See the voluminous NGCA, Artist's file, Emily Warren.

72. MUA, RG2, C51, file 681, "Warren, Miss Emily, Paintings, 1920-1933", Currie to McCurdy, 22 Nov. 1920; McCurdy to Currie 27 Nov. 1920; Currie to McCurdy, 2 Dec. 1920. Currie's views were passed on to the National Gallery: NGCA, 5.41.0, file: "Sir Edmund Walker": Currie to McCurdy, 22 Nov. 1920 (copy).

73. MUA, RG2, C51, file 681, "Warren, Miss Emily: paintings 1920-33", Currie to Bowman, 2 Dec. 1920.

74. MUA, RG2, C51, file 681, "Warren, Miss Emily, Paintings, 1920-1933", Currie to Warren, 4 July 1923; MUA, RG2, C48, file 549, "Royal Military College, 1919-1936", Currie to Macdonell, 26 Mar. 1924.

75. The two paintings "Canada's Tribute" are reproduced in Kryzanowski, Currie Hall, 33. See McRae, The light must be perfect, 38-43, 58-65, 119 . 124. The pair of paintings do not appear in the few available photographs of the interior of Moyse Hall, during the 1930s. Perhaps they hung outside the Hall in the foyer of the Arts Building.

76. MUA, RG4, C10, file 9013, Board of Governors minute book, 9 Aug. 1934, 21 Dec. 1934, 730, 732; MUA, RG4, C22, file 9028, Board of Governors Executive Committee minute book, 6 Nov. 1935, 5. Queries from McGill about the Orpen are documented in NGCA, 5. 41-0, Canadian War Art, "Offers for purchase / presentation of war art (N-Z)", Judah to McCurry, 24 Sept. 1934; McCurry to Judah, 28 Sept. 1934. MUA, RG4 C21, file 9027 , Board of Governors Finance Committee minute book, 24 Jan. 1934, 782.

77. MUA, UP, Correspondence, ca. 1930-42 (unsorted), McMurray to Urquhart, n.d.; MUA, Frank Shaughnessy Papers, MG 4141 (consisting of 2 letters), Currie to Shaughnessy, 16 Nov. 1931, 16? Oct. 1933. The student disruptions were reported in the Montreal
Gazette, 6 Nov. 1933. Leacock's tribute appeared in the Montreal Herald, 6 Dec. 1933 and is quoted by Dancocks, Sir Arthur Currie, 284-285 and Albert and Theresa Moritz, Leacock: a biography (Toronto, 1985), 258-260, and see 218. On Currie's last days see Urquhart, Arthur Currie, 354-357. Dorothy McMurray included a personal memoir of Currie in her Four Principals of McGill (Montreal, 1974). 